\title{
39. RADIOLARIAN PALEOGENE BIOSTRATIGRAPHY IN THE SOUTHERN INDIAN OCEAN, LEG 1201
}

\author{
Atsushi Takemura ${ }^{2}$
}

\begin{abstract}
During Ocean Drilling Program Leg 120, an almost complete Paleogene sediment section on the Kerguelen Plateau in the southern Indian Ocean was recovered. The biostratigraphy of radiolarians from these sediments at Sites 748 and 749 is studied. A biostratigraphic framework established in low and middle latitudes is not applicable because of the absence of most zonal marker species. Biogenic opal is present only in middle Eocene to Oligocene sediments, and three new zones-Lychnocanoma conica, Axoprunum(?) irregularis, and Eucyrtidium spinosum zones-are proposed. The Paleogene antarctic radiolarian fauna is different from that in low and middle latitudes. Three new species, Axoprunum(?) irregularis, Eucyrtidium cheni, and Eucyrtidium spinosum, are described.
\end{abstract}

\section{INTRODUCTION}

During Ocean Drilling Program (ODP) Leg 120, scientists drilled five sites in the Central and Southern Kerguelen plateaus of the southern Indian Ocean. Although Paleogene radiolarians were obtained from four sites (Sites 747-750), two sites have either poorly preserved shells (Site 747) or insufficient recovery (Site 750). For this study, I performed Paleogene radiolarian biostratigraphic work for Sites 748 and 749 .

Paleogene radiolarians from Leg 120 range in age from the middle Eocene to the late Oligocene. Although the radiolarian zonation of this interval has already been established for lowlatitude areas (Sanfilippo et al., 1985), this scheme cannot be applied to Leg 120 samples because of the absence of almost all zonal markers recognized in tropical or subtropical areas. For instance, genera Podocyrtis and Thyrsocyrtis, both of which are the most important groups for defining the middle to late Eocene zones, were not observed in Leg 120 samples at all.

Few previous studies of Paleogene radiolarians in the Antarctic Sea area exist. Petrushevskaya (1975) described many Paleogene forms from Deep Sea Drilling Project (DSDP) Leg 29. Chen (1975) treated Paleogene samples from Sites 264 and 274 of DSDP Leg 28, which have ages of Eocene and early Oligocene, respectively. He described radiolarians in these two assemblages, but no one has yet tried to zone a Paleogene interval in the Antarctic Sea. Weaver (1983) also reported on Paleogene radiolarians from the Falkland Plateau region in the southwest Atlantic. Although he studied middle Eocene to early Oligocene radiolarians and interpreted them from a paleoenvironmental perspective, he did not zone them, and no plates of Paleogene radiolarians appear in his study.

ODP has conducted several cruises in the Antarctic Sea area (Legs 113, 114, 119, and 120). During Leg 113, scientists recovered radiolarian-bearing Paleogene cores at several sites in the Weddell Sea (Barker, Kennett, et al., 1988). Abelmann (1990) studied the biostratigraphy of the late Oligocene to middle Miocene sequence from Sites 689 and 690. During Leg 114, seven sites were drilled in the subantarctic South Atlan-

\footnotetext{
1 Wise, S. W., Jr., Schlich, R., et al., 1992. Proc. ODP, Sci. Results, 120: College Station, TX (Ocean Drilling Program).

${ }^{2}$ Geoscience Institute, Hyogo University of Teacher Education, Yashirocho, Kato-gun, Hyogo 673-14, Japan.
}

tic, and many Paleogene cores (Paleocene to Oligocene) that included radiolarians were obtained (Ciesielski, Kristoffersen, et al., 1988). During Leg 119, northernmost and southernmost Kerguelen Plateau and Prydz Bay sites were drilled (Barron, Larsen, et al., 1989). Eocene and Oligocene radiolarians were reported from Sites 738 and 744 and, particularly, from Site 738 , where warmer fauna have been reported.

Until now, no Paleogene radiolarian zonation existed, except for that of Abelmann (1990). Paleogene radiolarians from Leg 120 contain many forms described by Petrushevskaya (1975) and Chen (1975). In particular, Site 748 contains a good Paleogene section for biostratigraphy composed of nannofossil oozes that include radiolarians, foraminifers, nannofossils, diatoms, and silicoflagellates. I conducted a biostratigraphic study using these samples and propose an original zonation of a Paleogene sequence.

\section{MATERIALS AND METHODS}

The samples used for this study were obtained from Holes $748 \mathrm{~B}\left(58^{\circ} 26.45^{\prime} \mathrm{S}, 78^{\circ} 58.89^{\prime} \mathrm{E}\right)$ and $749 \mathrm{~B}\left(58^{\circ} 43.03^{\prime} \mathrm{S}, 76^{\circ} 24.45^{\prime} \mathrm{E}\right)$. Sediments from these holes are composed mostly of calcareous sediments of Mesozoic and Cenozoic age (Schlich, Wise, et al., 1989).

At Hole 748B, Paleogene nannofossil oozes without porcellanite or chert (lithologic Subunit IIA) were drilled from Cores $120-748 \mathrm{~B}-9 \mathrm{H}$ to $-20 \mathrm{H}$. Cores $120-748 \mathrm{~B}-21 \mathrm{X}$ to $-23 \mathrm{X}$ are composed of nannofossil chalk, chert, and porcellanite (lithologic Subunit IIB). Paleogene radiolarians are contained in Cores $120-748 \mathrm{~B}-9 \mathrm{H}$ to $-19 \mathrm{H}$, and samples obtained from this interval were used for this study. Abundances and preservational states of the radiolarian shells from this interval generally became fewer and poorer with depth.

Samples of nannofossil ooze without chert were obtained from Sample $120-749 \mathrm{~B}-1 \mathrm{H}-1,24 \mathrm{~cm}$, to Core $120-749 \mathrm{~B}-5 \mathrm{H}$ (lithologic Subunit IIA), and Paleogene radiolarians were included with Cores $120-749 \mathrm{~B}-1 \mathrm{H}$ to $-3 \mathrm{H}$. Because Paleogene sediments in this interval (upper[?] Eocene to upper Oligocene) are thin, I did not treat the samples from this hole in numerical order.

Almost all samples $(45-47 \mathrm{~cm})$ from each section of these intervals from both holes were studied (Tables 1 and 2). First, these samples were processed with $\mathrm{HCl}$ (about $3 \%$ ), and then with $\mathrm{H}_{2} \mathrm{O}_{2}$ and sodium pyrophosphate. Residues produced by these processes were sieved through 250 -mesh $(63 \mu \mathrm{m})$. Dried 
Table 1. List of occurrences of radiolarians from Hole $748 \mathrm{~B}$ (Cores $120-748 \mathrm{~B}-9 \mathrm{H}$ to $-19 \mathrm{H}$ ).

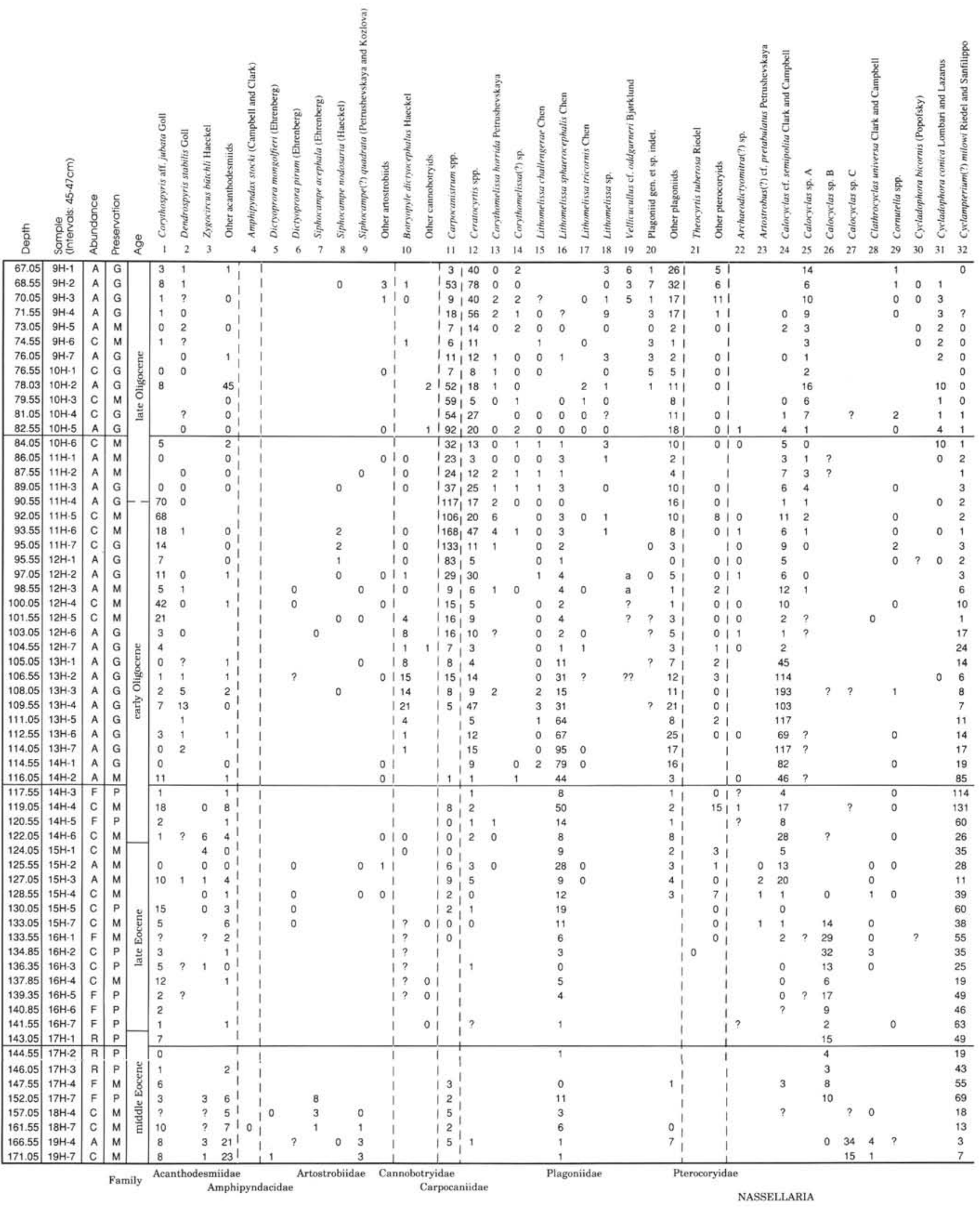

Notes: $\mathrm{A}=$ abundant, $\mathrm{C}=$ common, $\mathrm{F}=$ few, $\mathrm{R}=$ rare, $\mathrm{B}=$ barren, $\mathrm{G}=$ good, $\mathrm{M}=$ moderate, and $\mathrm{P}=$ poor. The number 0 in the list means presence was confirmed by observation after counting. 
Table 1 (continued).

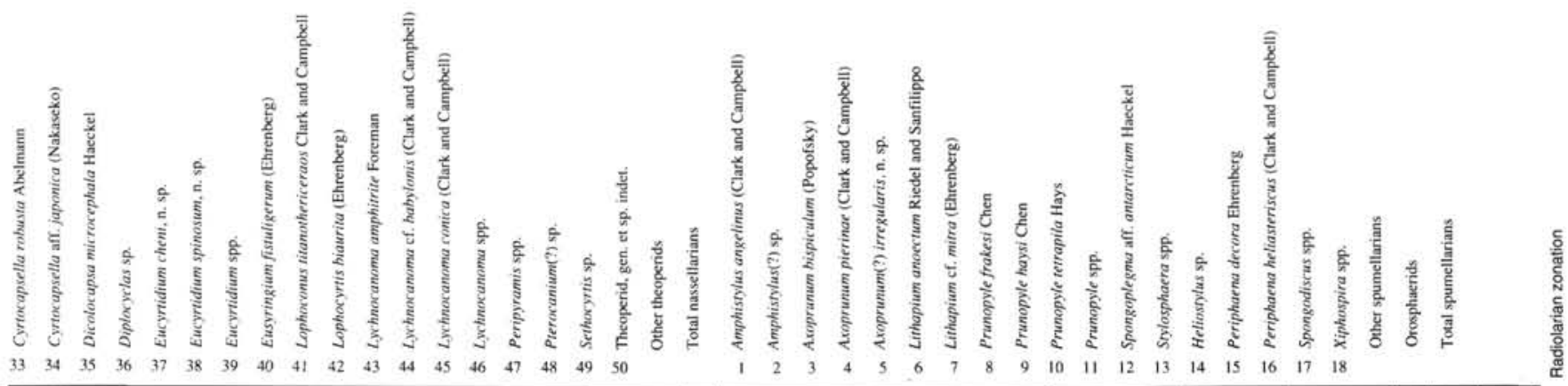

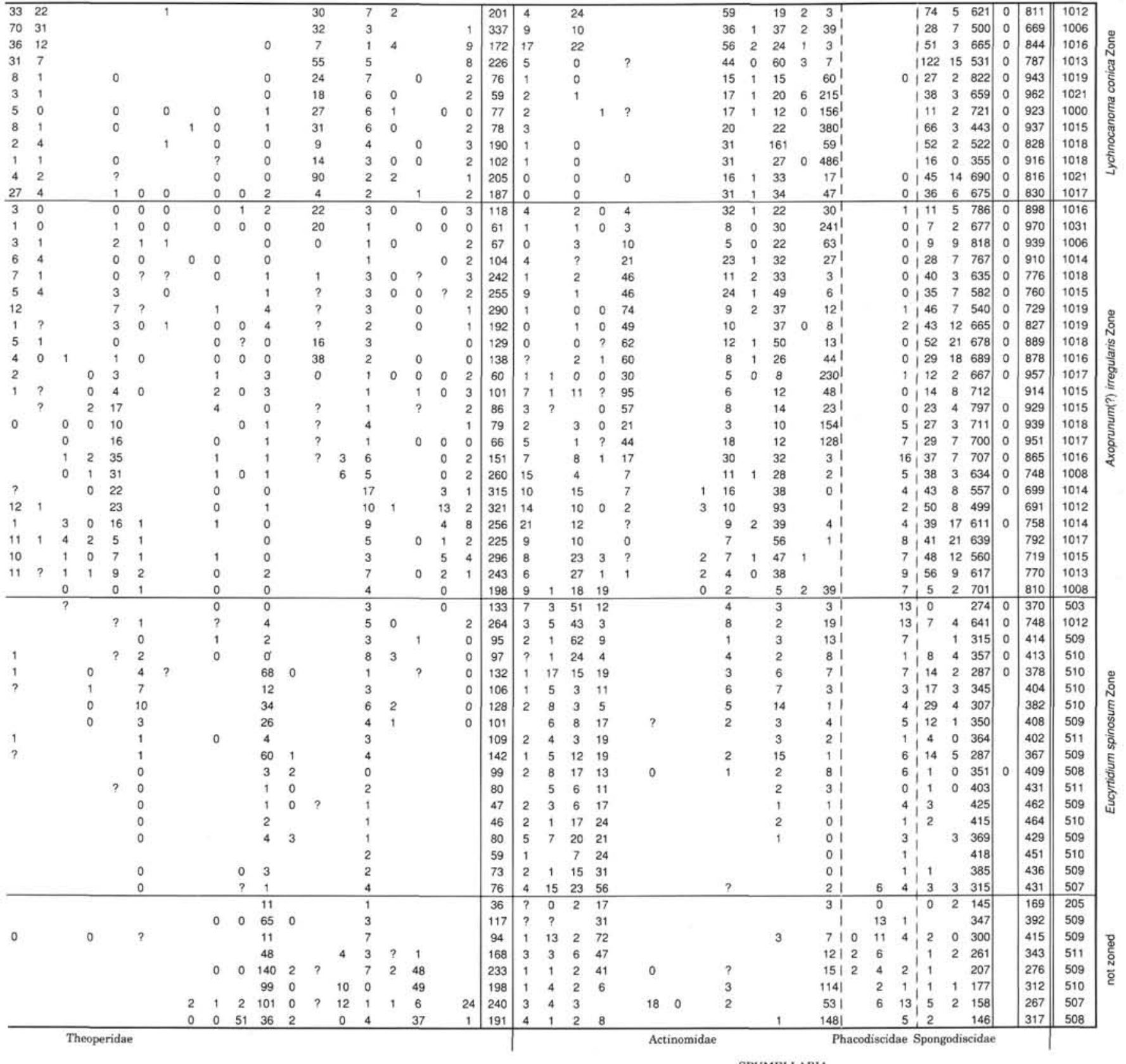

SPUMELLARIA 
Table 2. List of occurrences of radiolarians from Hole 749B.

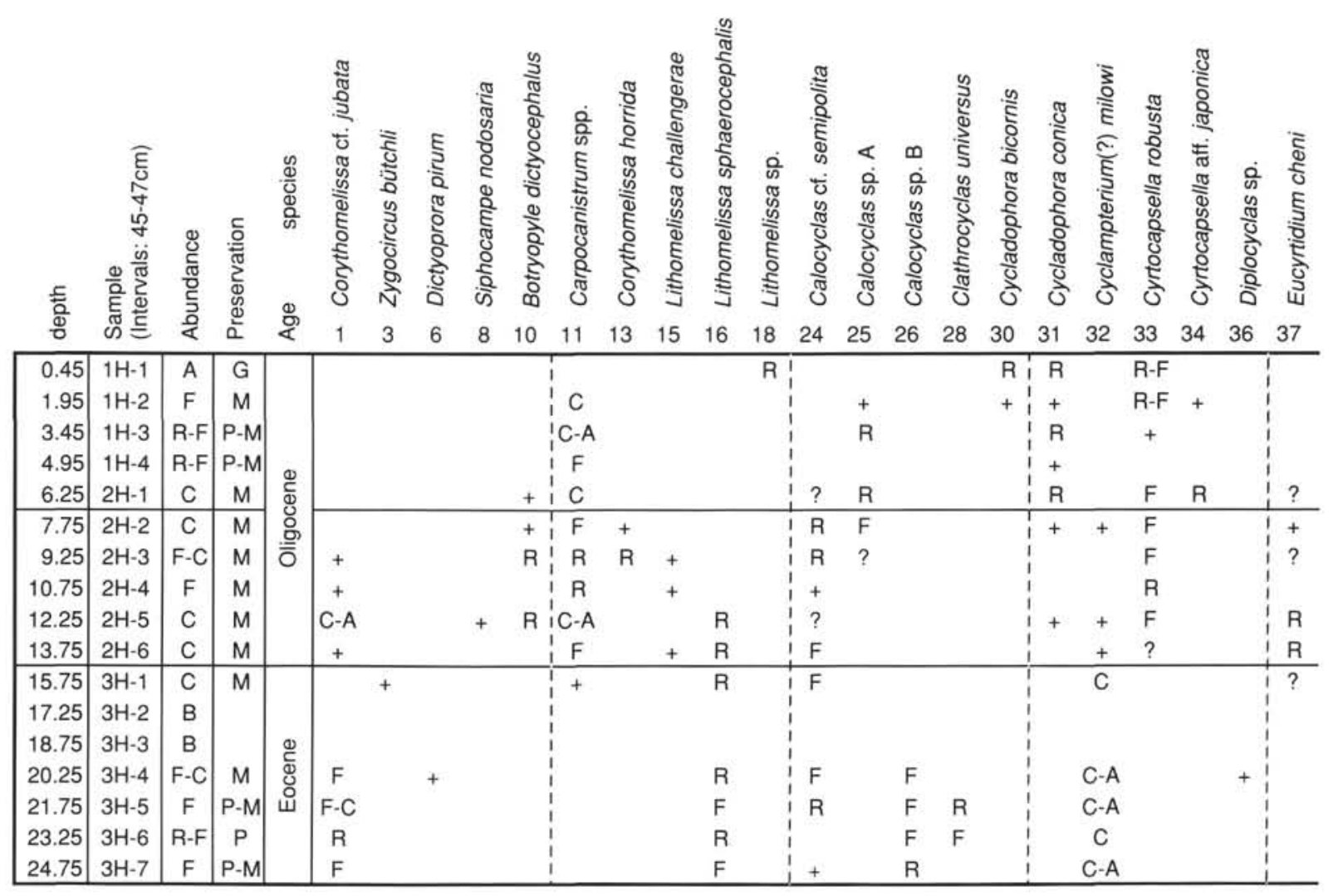

Note: Abbreviations are the same as those in Table 1.

residues were scattered on slides, on which thin gum tragacanth was spread and allowed to dry. After breathing lightly on each slide, radiolarian shells that did not adhere were allowed to fall off to be removed with a brush. Canada balsam and $22 \times 40 \mathrm{~mm}$ glass covers were used to mount the specimens.

Either 500 or 1000 (rarely 200) radiolarian shells from Hole 748B were counted for each sample. The Zeiss axioscope was used as light optic, and all radiolarian shells observed by $20 \times$ objective lens were counted as moving along a transverse line. After about 1000 (or 500) specimens were counted, I observed all the radiolarian shells mounted on the slides using less magnification. Many forms still have not been described. Furthermore, I was unable to describe all the forms that were found during Leg 120 here because too many undescribed forms exist and they are too scattered. As shown in Table 1, these forms were collected into families (for instance, other theoperids).

Abundances of each radiolarian species in Hole 749B (Fig. 1) have been classified into four categories: abundant (A), common $(\mathrm{C})$, few $(\mathrm{F})$, and rare $(\mathrm{R})$. Preservation is shown as good $(\mathrm{G})$, moderate $(\mathrm{M})$, or poor $(\mathrm{P})$ (Tables 1 and 2 ).

\section{RADIOLARIANS AT EACH SITE}

\section{Site 748}

An almost continuous Paleogene sequence was obtained from Hole 748B. The Oligocene/Miocene boundary was placed near Section 120-748B-8H-CC based on planktonic foraminifers, between Samples 120-748B-8H-CC and -9H-CC using nannofossil biomarkers, and just above Sample 120748B-8H-CC with diatoms (Schlich, Wise, et al., 1989). The first occurrence (FO) of Cyrtocapsella tetrapera (approximately $23 \mathrm{Ma}$ ) was recognized at Sample 120-748B-8H-4, $45-47 \mathrm{~cm}$.

Samples from Cores 120-748B-9H and -10H commonly contain Cyrtocapsella robusta, Cyrtocapsella aff. japonica, Lychnocanoma conica, Corythospyris aff. jubata, Calocyclas sp. A, and Prunopyle hayesi. Vellicucullus cf. oddgurneri appears in Sample 120-748B-9H-3, 45-47 cm. Rare specimens of Cyclampterium(?) milowi and Lychnocanoma amphitrite were observed, but these may have been reworked because most are fragments. Stylosphaera spp. with thick walls were abundant in some samples within this interval. The last occurrence (LO) of Lithomelissa sphaerocephalis was found in Sample 120-748B-9H-5, 45-47 cm, and that of Axoprunum(?) irregularis in Sample 120-748B-10H-6, 45-47 cm.

In Core 120-748B-11H, Lychnocanoma conica occurs in most samples, whereas Axoprunum(?) irregularis was often observed. Cyrtocapsella robusta and Calocyclas sp. A are abundant, and Corythospyris aff. jubata and Carpocanistrum spp. are abundant in lower samples from Core $120-748 \mathrm{~B}-11 \mathrm{H}$. Occurrences of Eucyrtidium cheni and E. spinosum are rare to few in Cores $120-748 \mathrm{~B}-10 \mathrm{H}$ and $-11 \mathrm{H}$, but the latter species may have been reworked because they usually occur as fragments. 
Table 2 (continued).

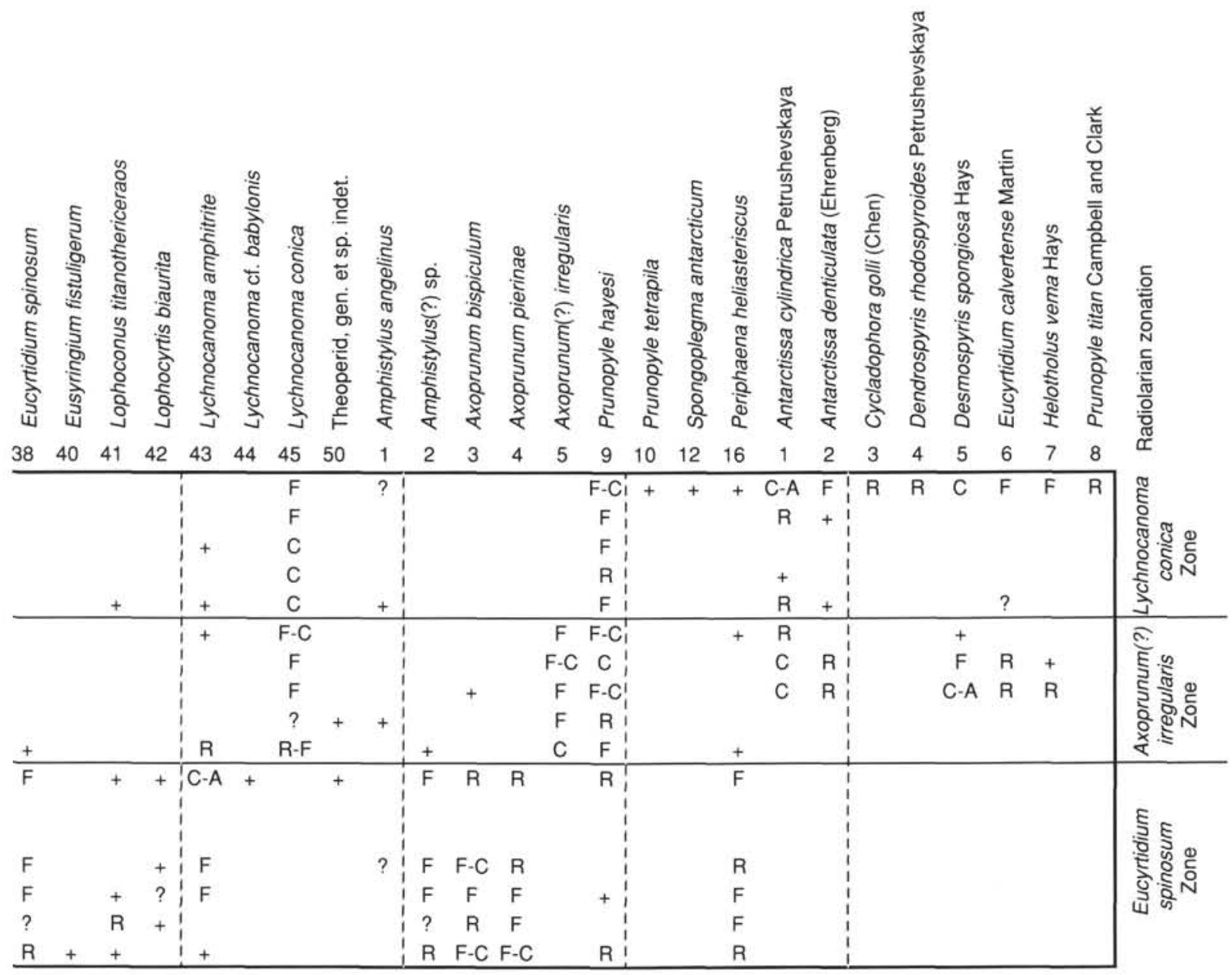

Core 120-748B-12H commonly contained Axoprunum irregularis, Cyclampterium(?) milowi, Eucyrtidium cheni, Calocyclas cf. semipolita, and Corythospyris aff. jubata. Calocyclas $\mathrm{sp}$. A and Lychnocanoma conica first appeared in Sample 120-748B-12H-3, 45-47 cm. In Core 120-748B-13H, Calocyclas cf. semipolita and Lithomelissa sphaerocephalis are abundant, and Eucyrtidium cheni, Cyclampterium(?) milowi, and Axoprunum bispiculum are also common. Abundances of Axoprunum(?) irregularis decreased with depth. The last continuous occurrence of Eucyrtidium spinosum was in Sample $120-748 \mathrm{~B}-13 \mathrm{H}-5,45-47 \mathrm{~cm}$.

In Core 120-748B-14H, Cyclampterium(?) milowi is sometimes abundant. Calocyclas cf. semipolita, Lithomelissa sphaerocephalis, Axoprunum bispiculum, and Axoprunum pierinae are common. Eucyrtidium spinosum was found instead of E. cheni. The FOs of Axoprunum irregularis and Eucyrtidium cheni were placed in Sample 120-748B-14H-1, $45-47 \mathrm{~cm}$, and $-14 \mathrm{H}-2,45-47 \mathrm{~cm}$, respectively. The LO of Amphistylus(?) sp. also was found in Sample 120-748B-14H-2, $45-47 \mathrm{~cm}$.

Core 120-748B-15H contained common Calocyclas cf. semipolita, Lithomelissa sphaerocephalis, Cyclampterium(?) milowi, Eucyrtidium spinosum, Lychnocanoma amphitrite, Amphistylus(?) sp., Axoprunum bispiculum, and A. pierinae. The LO of Calocyclas sp. B was placed in Sample 120-748B$15 \mathrm{H}-7,45-47 \mathrm{~cm}$. In Core 120-748B-16H, Calocyclas sp. B,
Cyclampterium(?) milowi, Axoprunum bispiculum, and Axoprunum pierinae are common.

Theocyrtis tuberosa was observed only in Sample 120748B-16H-2, 45-47 cm. This species appeared in the Thyrsocyrtis bromia Zone of the late Eocene and evolved to Theocyrtis annosa during the late Oligocene in low and middle latitudes. Its thoracic surface is definitely tubercle in late specimens, but it is less so in early ones (Sanfilippo et al., 1985). This feature, the thoracic surface, of the specimens from Hole $748 \mathrm{~B}$ is the same as that of these early specimens. Therefore, this horizon in Hole $748 \mathrm{~B}$ possibly may correlate with the $T$. bromia Zone of the late Eocene.

In Core 120-748B-17H, Cyclampterium(?) milowi and Axoprunum pierinae are abundant, and Lychnocanoma amphitrite may be abundant sometimes. The FO of Eucyrtidium spinosum was found in Sample 120-748B-17H-1, 45-47 cm. Calocyclas sp. B is common in Core $120-748 \mathrm{~B}-17 \mathrm{H}$, and the FO of this species was placed in Sample 120-748B-17H-7, 45-47 cm. The LO of Sethocyrtis sp. also could be seen in Sample $120-748 \mathrm{~B}-17 \mathrm{H}-7,45-47 \mathrm{~cm}$.

Cores 120-748B-18H and -19H contained Lychnocanium amphitrite and Sethocyrtis sp., usually in abundance. Cyclampterium(?) milowi and Axoprunum pierinae are often included. Calocyclas sp. C is common in the lower part of Core $120-748 \mathrm{~B}-19 \mathrm{H}$, and the LO of this species was placed in Sample 120-748B-19H-2, 45-47 cm. 


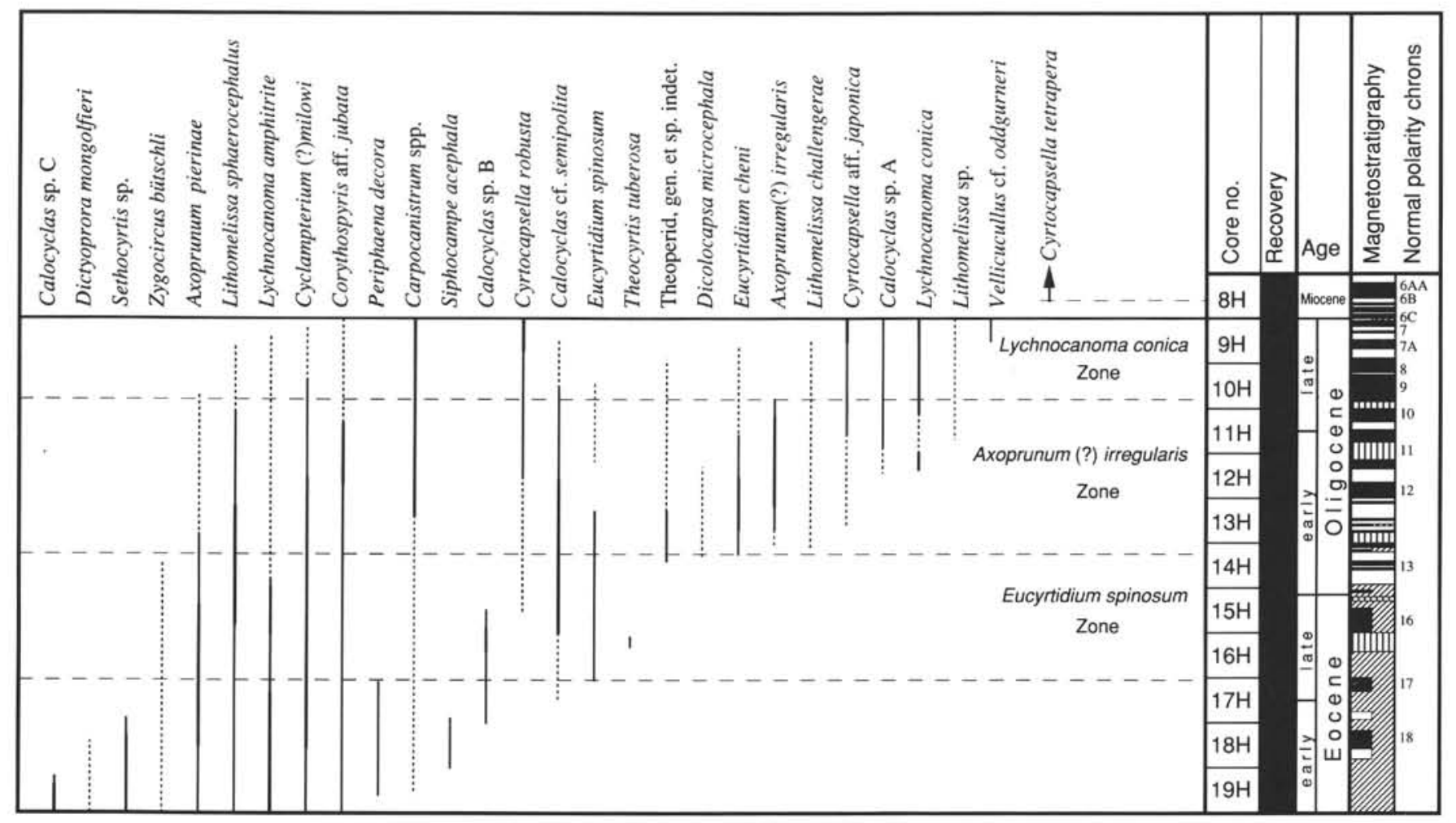

Figure 1. Ranges of Paleogene radiolarians from Hole 748B. Magnetostratigraphic data are after Schlich, Wise, et al. (1989).

\section{Site 749}

In Hole 749B, such Neogene species as Helotholus vema, Desmospyris spongiosa, and species of Antarctissa were observed in some samples of Cores 120-749B-1H and $-2 \mathrm{H}$ (Table 2). The occurrence of these species in Core 120749B-2H may result from downcore contamination.

Sections $120-749$ B-1H-1 to -2H-1 usually contained Lychnocanoma conica, Prunopyle haysei, Carpocanistrum spp., and Cyrtocapsella robusta. Axoprunum(?) irregularis occurred in Samples 120-749B-2H-2 to -2H-6. Eucyrtidium cheni also occurred in this interval. Core $120-749 \mathrm{~B}-3 \mathrm{H}$ contained Cyclampterium(?) milowi, Eucyrtidium spinosum, Amphistylus(?) sp., Axoprunum bispiculum, and A. pierinae.

\section{PALEOGENE RADIOLARIAN ZONES}

Recently, Abelmann (1990) proposed two zones for the upper Oligocene from ODP Leg 113: the Stylosphaera radiosa and Cyrtocapsella robusta zones. Although she settled the bases of these zones at 27.2 and $27.7 \mathrm{Ma}$ in the upper Oligocene sequence, respectively, the base of the occurrence of $C$. robusta was situated in the upper Eocene or lower Oligocene at Site 748. However, Stylosphaera has numerous forms, and I could not reasonably divide them into species here. Abelmann's (1990) occurrence data show that her lowest samples just below the $S$. radiosa Zone or the $C$. robusta Zone always have poor preservation and have rare or trace abundances. One finds it difficult to define the bases of these zones using her data.

Therefore, I propose three new zones here for the late Eocene(?) to late Oligocene sequence, described next. Other biostratigraphic and magnetostratigraphic data and the estimated absolute ages of radiolarian events are referred from those of Schlich, Wise, et al. (1989) and Berggren et al. (1985).

\section{Lychnocanoma conica Zone}

Top. FO of Cyrtocapsella tetrapera.

Base. LO of Axoprunum(?) irregularis.

Remarks. At Hole 748B, Cyrtocapsella tetrapera is a good indicator of the Oligocene/Miocene boundary and also is an important zonal marker for the early Miocene in low and middle latitudes. Lychnocanoma conica was adopted as a zone name because it is common and continuous within this zone.

Age. Early late Oligocene to earliest Miocene(?), 29.2-23.0 Ma.

Site 748. Top: Sample 120-748B-8H-4, $45-47 \mathrm{~cm}(62.05 \mathrm{mbsf})$; this horizon is situated within the normal paleomagnetic period, at about 60 mbsf, which correlates to Subchrons 6AA and 6B. Base: Sample $120-748 \mathrm{~B}-10 \mathrm{H}-6,45-47 \mathrm{~cm}$ ( $84.05 \mathrm{mbsf})$; the normal period between 79 and 84 mbsf correlates to Chron 9 of the late Oligocene.

Site 749. Samples $120-749 \mathrm{~B}-1 \mathrm{H}-1,45-47 \mathrm{~cm}(0.45 \mathrm{mbsf})$, to $-2 \mathrm{H}-2$, $45-47 \mathrm{~cm}$ (7.75 mbsf).

Assemblage. Lychnocanoma conica, Cyrtocapsella robusta, Cyrtocapsella aff. japonica, Calocyclas sp. A, Carpocanistrum spp., Stylosphaera spp., Prunopyle hayesi.

Other biohorizons. FOs include Vellicucullus cf. oddgurneri (26.1 $\mathrm{Ma}$ within this zone. LOs include Lithomelissa challengerae and Lithomelissa sphaerocephalis.

\section{Axoprunum(?) irregularis Zone}

Top. Last continuous occurrence of Axoprunum(?) irregularis. Base. FO of Eucyrtidium cheni.

Remarks. Near the base of this zone, the transition from Eucyrtidium spinosum to Eucyrtidium cheni was recognized. The FO of Axoprunum(?) irregularis is just above the base of this zone. In Site 748 , few specimens of A.(?) irregularis were found in Sample 120$748 \mathrm{~B}-10 \mathrm{H}-4,45-47 \mathrm{~cm}$ (Table 1). This species is abundant or common in samples lower than Sample 120-748B-10H-6, 45-47 cm, and was never found in any upper samples, except in Sample 120-748B-10H-4, $45-47 \mathrm{~cm}$. A.(?) irregularis in Sample $120-748 \mathrm{~B}-10 \mathrm{H}-4,45-47 \mathrm{~cm}$, may be reworked and, therefore, at Site 748 the top of this zone has been settled at Sample 120-748B-10H-6, $45-47 \mathrm{~cm}$, in this study.

Age. Early Oligocene to early late Oligocene, 35.0-29.2 Ma. 
Site 748. Top: Sample 120-748B-10H-6, $45-47 \mathrm{~cm}$ (84.05 mbsf). Base: Sample 120-748B-14H-2, 45-47 cm (116.05 mbsf). This horizon may correlate to Chrons 12 or 13 in the early Oligocene.

Site 749. Samples 120-749B-2H-2, 45-47 cm (7.75 mbsf), to 120-749B-2H-6, 45-47 cm (13.75 mbsf).

Assemblage. Axoprunum(?) irregularis, Lithomelissa sphaerocephalis, Calocyclas cf. semipolita, Cyrtocapsella robusta, Carpocanistrum spp., Cyclampterium(?) milowi, Eucyrtidium cheni, and Corythomelissa aff. jubata.

Other biohorizons. FOs include Calocyclas sp. A (32.0 Ma), Lychnocanoma conica (32.0 Ma), Lithomelissa challengerae $(34.8$ Ma), and Axoprunum(?) irregularis (34.8 Ma). LOs include Dicolocapsa microcephala and the continuous sequence of Eucyrtidium spinosum (33.8 Ma).

\section{Eucyrtidium spinosum Zone}

Top. FO of Axoprunum(?) irregularis.

Base. FO of Eucyrtidium spinosum.

Age. Near the boundary between middle and late Eocene to early Oligocene, about 40-34.8 Ma.

Site 748. Top: Sample 120-748B-14H-1, 45-47 cm (114.58 mbsf). Base: Sample 120-748B-17H-1, 45-47 cm (143.05 mbsf). This horizon is situated within a less reliable normal period and correlates to Chron 17.

Site 749. Samples $120-749 \mathrm{~B}-2 \mathrm{H}-6,45-47 \mathrm{~cm}$ (13.75 mbsf), to $-3 \mathrm{H}-7,45-47 \mathrm{~cm}$ ( $24.75 \mathrm{mbsf}$ ).

Assemblage. Eucyrtidium spinosum, Cyclampterium(?) milowi, Lychnocanoma amphitrite, Axoprunum pierinae, Axoprunum bispiculum, Amphistylus(?) sp., and Calocyclas cf. semipolita.

Other biohorizons. FOs include Eucyrtidium cheni $(35.0 \mathrm{Ma})$, Dicolocapsa microcephala (35.0 Ma), and Theoperid, gen. et sp. indet. (37.4 Ma). LOs include Calocyclas sp. B, Zygocircus bütschlii, and Amphistylus(?) sp. Theocyrtis tuberosa occurs in upper Eocene sediments between normal polarity Chrons 16 and 17 (ca. $39.4 \mathrm{Ma}$ ).

Cores $120-748 \mathrm{~B}-17 \mathrm{H}$ to $-19 \mathrm{H}$ are not zoned here (mostly middle Eocene in age). However, some biohorizons were recognized within this interval. These include the FO of Calocyclas sp. B, and the LOs of Sethocyrtis sp. and Calocyclas $\mathrm{sp}$. C.

The radiolarian zonation of Sites 748 and 749 is different from that of radiolarians in low latitudes. The species for which ranges were determined in low latitudes (Sanfilippo et al., 1985) and that occur in Leg 120 samples are Dictyoprora mongolfieri, Eusyringium fistuligerum, Dictyoprora pirum, and Theocyrtis tuberosa. Important zonal marker species belonging to the genera Podocyrtis, and Thyrsocyrtis were not observed in Leg 120 samples. Although Riedel and Sanfilippo (1978) determined the ranges of Cyclampterium(?) milowi and Lychnocanoma amphitrite, the ranges of these species in Leg 120 samples seem to be different from those of low latitudes.

During Leg 119 (Barron, Larsen, et al., 1989), six sites also were drilled on the Kerguelen Plateau, and Paleogene radiolarians were reported from two sites (738 and 744) in the southernmost part. Oligocene radiolarians occurred in Site 744 , but no zonal markers from low latitudes were included. Furthermore, Oligocene low-latitude fauna have not been reported from other sites in the Antarctic region (Petrushevskaya, 1975; Chen, 1975; Weaver, 1983; Barker, Kennett, et al., 1988; Ciesielski, Kristoffersen, et al., 1988; Abelmann, 1990). These data suggest that the ocean current system of the antarctic region was different in low latitudes during Oligocene time.

Barron, Larsen, et al. (1989) reported the occurrence of Eocene radiolarians from Site 738. In the upper middle Eocene sections of this site (Samples 119-738B-16X-CC to $-18 \mathrm{X}-\mathrm{CC}$ ), many tropical forms, including $P$. chalara, were found. Although strict correlation between this interval and Core $120-748 \mathrm{~B}-19 \mathrm{H}$ is difficult at present, both these intervals are middle Eocene; the first appearance datum of the plank- tonic foraminifer $G$. index was reported at Core 119-738B-19X and Sample 120-748B-20H-CC (Table 3). Thus, some transition of radiolarian fauna may have occurred during the middle Eocene.

\section{SYSTEMATIC DESCRIPTION}

The higher level (family level) taxonomy adopted for this study is after Riedel $(1967,1971)$. All specimens, including prototypes, have been deposited at the Geoscience Institute, Hyogo University of Teacher Education, Japan.

Subclass RADIOLARIA Müller

Order POLYCYSTINA Ehrenberg, emend. Riedel Suborder SPUMELLARIA Ehrenberg

Family ACTINOMMIDAE Haeckel, emend. Riedel Genus AMPHISTYLUS Haeckel, 1881

Amphistylus angelinus (Campbell and Clark) (Plate 1, Figs. 8-9)

Amphistylus angelinus (Campbell and Clark) Chen, 1975, p. 453, pl. 21, figs. 3-4.

Occurrence. middle Eocene to Oligocene, rare to common.

\section{Amphistylus(?) sp.}

(Plate 5, Figs. 9-10)

Description. Cortical shell is similar to that of A. angelinus but usually smaller than the latter. One polar spine is rodlike, strong, and longer than the diameter of cortical shell. Other spines, when they exist, are conical, thin, and short. At least several bars connect medullary and cortical shells, but internal structures, including medullary shells, are obscure because of poor preservation.

Measurements. Diameter of cortical shell is $100-140 \mu \mathrm{m}$; length of long polar spine is $130-195 \mu \mathrm{m}$, measured in six specimens.

Remarks. Although internal structures of this species were not observed, this species is tentatively included within Genus Amphistylus because of the similarity of its cortical shell to Amphistylus angelinus.

Occurrence. middle Eocene to early Oligocene, few to common.

\section{Genus AXOPRUNUM Haeckel, 1887}

Axoprunum Haeckel, 1887, p. 298.

Stylacontarium Popofsky, 1912, p. 90.

Remarks. Petrushevskaya and Kozlova (1972) described this genus minutely. Sanfilippo and Riedel (1973) adopted this genus name for describing the $A$. pierinae group. Here, 1 follow their taxonomy and use this name for all ellipsoidal forms having one cortical and two medullary shells and two polar spines, which usually are conical or rodlike. Kling (1973) described both genera, Axoprunum and Stylacontarium, but used Axoprunum for A. angelinum, which was assigned to the genus Amphistylus by Chen (1975).

\section{Axoprunum bispiculum (Popofsky) n. comb.} (Plate 1, Figs. 1-2)

Stylacontarium bispiculum Popofsky, 1912, p. 91, pl. 2, fig. 2; Chen, 1975 , p. 454 , pl. 21, figs. 1-2.

Remarks. Chen (1975) described this species under the genus Stylacontarium. However, the shell shape and structure of this species are nearly the same as those of Axoprunum pierinae (Clark

Table 3. Correlation between the Paleogene section of Holes 748B and 749B.

\begin{tabular}{|c|c|c|c|}
\hline & $748 B$ & $749 B$ & radiolarian zones \\
\hline \multirow[t]{2}{*}{ top } & $8 \mathrm{H}-4,45-47 \mathrm{~cm}$ & $1 \mathrm{H} \cdot 1.45-47 \mathrm{~cm}$ & \multirow{3}{*}{ Lychnocanoma conica Zone } \\
\hline & & & \\
\hline base & $10 \mathrm{H}-6,45-47 \mathrm{~cm}$ & $2 \mathrm{H}-2,45-47 \mathrm{~cm}$ & \\
\hline \multirow[t]{2}{*}{ top } & $10 \mathrm{H} \cdot 6,45-47 \mathrm{~cm}$ & $2 \mathrm{H}-2,45-47 \mathrm{~cm}$ & \multirow{3}{*}{ Axoprunum(?) irregularis Zon } \\
\hline & & & \\
\hline base & $14 \mathrm{H}-2,45-47 \mathrm{~cm}$ & $2 \mathrm{H} \cdot 6,45-47 \mathrm{~cm}$ & \\
\hline \multirow[t]{2}{*}{ top } & $14 \mathrm{H}-2,45-47 \mathrm{~cm}$ & $2 \mathrm{H} \cdot 6,45 \cdot 47 \mathrm{~cm}$ & \multirow{3}{*}{ Eucyrtidium spinosum Zone } \\
\hline & & & \\
\hline base & $17 \mathrm{H}-1,45-47 \mathrm{~cm}$ & $3 \mathrm{H}-6,45.47 \mathrm{~cm}$ & \\
\hline
\end{tabular}


and Campbell) group, described by Sanfilippo and Riedel (1973). Therefore, this species has been assigned to the genus Axoprunum here.

This species differs from A. pierinae (Clark and Campbell) in that it has a thinner shell and polar spines. However, differences between these two species are not clear, and these two species may be continuous in Eocene time.

Occurrence. Eocene to Oligocene, rare to common.

\section{Axoprunum pierinae (Clark and Campbell) (Plate 6, Figs. 3-6)}

Lithatractus pierinae Clark and Campbell, 1942, p. 34, pl. 5, fig. 25. Axoprunum pierinae (Clark and Campbell) group; Sanfilippo and Riedel, 1973 (in part), p. 488, pl. 1, figs. 6-9, pl. 23, fig. 3. Axoprunum lithostylum (Ehrenberg) group, Petrushevskaya, 1975, p. 571, pl. 2, fig. 22.

Remarks. Here, this species has been distinguished from $A$. bispiculum by only thickness of shells and polar spines. Lithatractus pierinae, described by Clark and Campbell (1942), has somewhat thin polar spines. Sanfilippo and Riedel (1973) mentioned that polar spines of Axoprunum pierinae group are variable in size and form. Here, I use this species name for forms usually having an ellipsoidal cortical shell and double medullary shells and thick polar spines. Some specimens have thicker, more columnar spines and a thick-walled cortical shell (Plate 6, Figs. 3-4). I cannot propose this form as another species because many variations exist in the shape of its cortical shell and polar spines.

Occurrence. Eocene to early Oligocene; only fragments occur in the lower upper Oligocene part of Hole 748B (Table 1), rare to common.

\section{Axoprunum(?) irregularis $\mathrm{n}$. $\mathrm{sp}$.}

(Plate 3, Figs. 8-11)

Actinomma medusa (Ehrenberg) group, Petrushevskaya, 1975 (in part), pl. 2, figs. 6-8.

(?)Amphisphaera sp. Chen, 1975 (in part), p. 453, pl. 6, fig. 2.

Description. This species has a cortical shell that is irregularly shaped or nearly polygonal in section, with two polar spines. In some specimens, the cortical shell is thick with a thorny surface. The pores on the cortical shell are circular to elliptical and vary in size. Two medullary shells are nearly spherical or ellipsoidal and are joined to the cortical shell by more than six bars. The two polar spines are rodlike or conical and are not bladed without basal portion. These spines are usually not situated on a single line and often are not joined with bars that connect cortical and medullary shells. In earlier specimens, the polar spines sometimes are longer than in the later specimens, and sometimes they are joined with bars to the medullary shell.

Measurements. Diameter of cortical shell is $140-195 \mu \mathrm{m}$; length of shell, including two polar spines is $230-290 \mu \mathrm{m}$, measured in 11 specimens.

Type. Holotype: HUTE-R-4001, Sample 120-748B-11H-4, 45-47 $\mathrm{cm}$ (Plate 3, Figs. 8-9). Paratype: HUTE-R-4002, Sample 120-748B$12 \mathrm{H}-7,45-47 \mathrm{~cm}$ (Plate 3, Figs. 10-11)

Remarks. Axoprunum(?) irregularis n. sp. differs from other species belonging to this genus in its irregularly shaped cortical shell and its two polar spines. This species was tentatively included within the genus Axoprunum because in earlier times (early Oligocene), some specimens were an intermediate type between this species and $A$. bispiculum and because this species might have evolved from the latter species. However, during the Eocene, a species existed that has a similar shell structure to A.(?) irregularis as well as long, threebladed polar spines. The phylogenetic problem of this species cannot be solved here.

Occurrence. Oligocene, few to common.

Genus LITHAPIUM Haeckel, 1887

Lithapium anoectum Riedel and Sanfilippo

(Plate 7, Fig. 1)

Lithapium anoectum Riedel and Sanfilippo, 1970, p. 520, pl. 4, figs. 4-5.

Occurrence. middle Eocene, common.
Lithapium cf. mitra (Ehrenberg)

(Plate 7, Fig. 2)

Lithapium mitra (Ehrenberg) Riedel and Sanfilippo, 1970, p. 520, pl. 4, figs. 6-7.

Remarks. From Sample 120-748B-19H-4, $45-47 \mathrm{~cm}$; both $L$. anoectum and $L$. cf. mitra were observed. Following Riedel and Sanfilippo (1978), the transition from $L$. anoectum to $L$. mitra occurred in the middle Eocene Podocyrtis mitra Zone in tropical areas.

Occurrence. middle Eocene, rare.

\section{Genus PRUNOPYLE Dreyer, 1889}

\section{Prunopyle frakesi Chen}

Prunopyle frakesi Chen, 1975, p. 454, pl. 10, figs. 1-3.

Occurrence. early Oligocene, rare; this large-sized species seems to occur usually as fragments in Leg 120 samples.

Prunopyle hayesi Chen

(Plate 1, Figs. 13-14)

Prunopyle hayesi Chen, 1975, p. 454, pl. 9, figs. 3-5.

Remarks. The hexagonally framed pores, which are regarded as a distinctive character by Chen (1975), can hardly be observed in Leg 120 specimens. For this study, many forms that have no hexagonally framed pores are included in this species.

Occurrence. Eocene to late Oligocene, few to common.

\section{Prunopyle tetrapila Hays}

(Plate 2, Figs. 1-2)

Prunopyle tetrapila Hays, 1965, p. 172, pl. II, fig. 5

Occurrence. Oligocene, rare.

\section{Prunopyle spp.}

Remarks. The small-sized ellipsoidal forms with pylome here are included under this name. These forms may correspond to Prunopyle sp. B group and Prunopyle sp. D of Abelmann (1990).

Occurrence. Eocene to Oligocene, few to common.

Genus SPONGOPLEGMA Haeckel, 1881

Spongoplegma aff. antarcticum Haeckel

(Plate 2, Figs. 9-10)

Spongoplegma antarcticum Haeckel, 1887, p. 90; Hays, 1965, pp. 165-167, pl. 1, fig. 1.

Remarks. The cortical shell of this species is thin and latticed and has irregularly distributed pores. However, its medullary spongy network is the same as that of $S$. antarcticum.

Occurrence. Oligocene, rare to few.

\section{Genus STYLOSPHAERA Ehrenberg, 1847}

\section{Stylosphaera spp.}

Remarks. Abelmann (1990) described some species of the genus Stylosphaera. However, this group includes various forms, and large variations were observed within each form. I cannot reasonably divide this group into species here.

Occurrence. middle Eocene to Oligocene, few to abundant.

$$
\begin{aligned}
& \text { Family PHACODISCIDAE Haeckel } \\
& \text { Genus HELIOSTYLUS Haeckel, } 1881
\end{aligned}
$$

Heliostylus Haeckel, 1881; Sanfilippo and Riedel, 1973, p. 522.

\section{Heliostylus sp.}

(Plate 6, Fig. 7)

Heliostylus sp. Sanfilippo and Riedel, 1973, p. 522, pl. 8, figs. 3-5, pl. 26, fig. 10.

Description. The cortical shell is lenticular and has two stout, long, and rodlike spines, which are unequal in length and are situated at nearly the opposite side. The cortical shell has a thick wall, with a smooth surface and hexagonally distributed, small, numerous pores. Two bars connect the cortical and medullary shells and extend to two 
outer spines. The medullary shell is indistinct because of poor preservation of this species.

Remarks. This species is the same as some forms reported as Heliostylus spp. by Sanfilippo and Riedel (1973).

Occurrence. middle Eocene, rare to few.

Genus PERIPHAENA Ehrenberg, 1873

Periphaena Ehrenberg, 1873; Sanfilippo and Riedel, 1973, pp. 522-523.

\section{Periphaena decora Ehrenberg}

(Plate 6, Fig. 8)

Periphaena decora Ehrenberg, 1873, p. 246; Sanfilippo and Riedel, 1973 , p. 523 , pl. 8 , figs. $8-10$, pl. 27 , figs. $2-5$.

Occurrence. middle Eocene, few to common.

Periphaena heliasteriscus (Clark and Campbell) (Plate 4, Fig. 13)

Periphaena heliasteriscus (Clark and Campbell) Sanfilippo and Riedel, 1973, p. 523 , pl. 9, figs. 1-6, pl. 27, figs. 8-9.

Occurrence. middle Eocene to late Oligocene, rare to common.

Family SPONGODISCIDAE Haeckel, emend. Riedel

Genus SPONGODISCUS Ehrenberg

Spongodiscus spp.

Occurrence. middle Eocene to Oligocene, rare to abundant.

Genus XIPHOSPIRA Haeckel

Xiphospira Haeckel, 1887; Sanfilippo and Riedel, 1973, p. 526. Xiphospira spp.

Occurrence. middle Eocene to Oligocene, rare to common.

Suborder NASSELLARIA Ehrenberg, 1875

Family ACANTHODESMIIDAE Haeckel, 1862

Genus CORYTHOSPYRIS Haeckel, 1881, emend. Goll, 1978

Corythospyris aff. jubata Goll

(Plate 3, Figs. 3-4)

aff. Corythospyris jubata Goll, 1978, pp. 177-178, pl. 4, figs. 1, 2, 4, 5, and $7-17$.

Corythospyris sp. A, Abelmann, 1990, pl. 5, figs. 6A-6B.

Remarks. This species resembles Corythospyris fiscela Goll, as described by Abelmann (1990) in that it has sulcate basal spines. It differs from $C$. jubata Goll in not having any irregularly protruding lattice spines and in having smaller pores on its shell surface. Earlier forms of this species rarely have sulcate basal spines.

Occurrence. middle Eocene to Oligocene, common to rare.

Genus DENDROSPYRIS Haeckel, 1881, emend. Goll, 1968

\section{Dendrospyris stabilis Goll \\ (Plate 4, Fig. 7)}

Dendrospyris stabilis Goll, 1968 , pp. 1422-1423, pl. 173, figs. 16-18 and 20 ; Chen, 1975 , p. 455 , pl. 7 , fig. 3.

Occurrence. Oligocene, rare to few.

Genus ZYGOCIRCUS Bütschli, 1882, emend. Petrushevskaya, 1971

\section{Zygocircus bütschli Haeckel}

(Plate 5, Fig. 4)

Zygocircus bütschli Haeckel, 1887, p. 948; Petrushevskaya and Kozlova, 1972, p. 534, pl. 41, figs. 8-11.

Occurrence. Eocene to earliest Oligocene, rare to few.

\section{Family AMPHIPYNDACIDAE Riede \\ Genus AMPHIPYNDAX Foreman, 1966}

Amphipyndax stocki (Campbell and Clark)

(Plate 6, Figs. 10-11)

Amphipyndax stocki (Campbell and Clark) Foreman, 1968, p. 78, pl. 8 , figs. $12 \mathrm{a}-12 \mathrm{c}$.
Remarks. Very rare specimens of this species occurred only in Sample 120-748B-18H-7, 45-47 cm, with an age of middle Eocene. This species has been reported mainly from the Cretaceous, but Dumitrica (1973) reported this species from a Paleocene sequence obtained during DSDP Leg 21. Although the occurrence of this species is rare (in only one sample), shell preservation is not bad (same as other Eocene radiolarians). Amphipyndax may have survived from the Cretaceous to the Eocene in the Antarctic Sea, but a rather large possibility of reworking exists.

Occurrence. Only in Sample 120-748B-18H-7, 45-47 cm, middle Eocene, rare.

Family ARTOSTROBIIDAE Riedel

Genus DICTYOPRORA Haeckel, 1881, emend. Nigrini, 1977

Dictyoprora mongolfieri (Ehrenberg)

(Plate 7, Fig. 12)

Eucyrtidium mongolfieri Ehrenberg, 1854, pl. 36, fig. 18.

Dictyoprora mongolfieri (Ehrenberg) Nigrini, 1977, pp. 250-251, pl. 4, fig. 7.

Occurrence. middle Eocene in Hole 748B, rare.

\section{Dictyoprora pirum (Ehrenberg)}

(Plate 5, Fig. 11)

Eucyrtidium pirum Ehrenberg, 1873, p. 232.

Dictyoprora pirum (Ehrenberg) Nigrini, 1977, p. 251, pl. 4, fig. 8.

Occurrence. late Eocene to Oligocene, rare.

Genus SIPHOCAMPE Haeckel, 1881, emend. Nigrini, 1977

\section{Siphocampe acephala (Ehrenberg)}

(Plate 6, Fig. 9)

Eucyrtidium acephalum Ehrenberg, 1875, p. 70, pl. 11, fig. 5.

Siphocampe acephala (Ehrenberg) Nigrini, 1977, pp. 254-255, pl. 3 , fig. 5 .

Occurrence. middle Eocene to Oligocene, few to rare.

\section{Siphocampe nodosaria (Haeckel)}

(Plate 3, Fig. 15)

Lithomitra nodosaria Haeckel, 1887, p. 1484, pl. 79, fig. 1.

Siphocampe nodosaria (Haeckel) Nigrini, 1977, pp. 256-257, pl. 3 , fig. 11.

Occurrence. middle Eocene, Oligocene, rare to few.

Siphocampe(?) quadrata (Petrushevskaya and Kozlova)

(Plate 7, Fig. 7)

Lithamphora sacculifera (Clark and Campbell) Petrushevskaya and Kozlova, 1972, p. 539, pl. 30, figs. 4-6.

Lithamphora quadrata (Petrushevskaya and Kozlova) Petrushevskaya, 1975 , p. 585 , pl. 10, figs. 19-20.

Siphocampe(?) quadrata (Petrushevskaya and Kozlova) Nigrini, 1977 , p. 257 , pl. 3 , fig. 12.

Occurrence. middle Eocene to Oligocene, few to rare.

Family CANNOBOTRYIDAE Haeckel, emend. Riedel Genus BOTRYOPYLE Haeckel, 1881

Botryopyle dictyocephalus Haeckel group (Plate 3, Fig. 7)

Botryopyle dictyocephalus Haeckel, 1887, p. 1113, pl. 96, fig. 6 .

Botryopyle dictyocephalus Haeckel group, Riedel and Sanfilippo, 1971 , p. 1602 , pl. $1 \mathrm{~J}$, figs. $21-26$, pl. $2 \mathrm{~J}$, figs. $16-18$, pl. $3 \mathrm{~F}$, figs. 9-12.

Botryocella spp. aff. B. cribrosa (Ehrenberg) group, Petrushevskaya and Kozlova, 1972, p. 554, pl. 39, figs. 4-6.

Botryocella(?) appeninica Vinassa de Regny group, Petrushevskaya, 1975 , p. 589 , pl. 13 , figs. 16 and 23

(?)Botryopyle(?) sp. Petrushevskaya, 1975, pl. 13, fig. 15.

Remarks. Although Petrushevskaya and Kozlova (1972) and Petrushevskaya (1975) described several species, their taxonomy seems to be too split. Here, these forms have been assigned to $B$. 
dictyocephalus Haeckel group, following Riedel and Sanfilippo (1971). Occurrence. Oligocene, rare to common.

Family CARPOCANIIDAE Haeckel, emend. Riedel Genus CARPOCANISTRUM Haeckel, 1887

Carpocanistrum spp.

(Plate 3, Figs. 5-6)

Carpocanistrum spp. Riedel and Sanfilippo, 1971, p. 1596, pl. 1G, figs. 1-6 and 8-13, pl. 2F, figs. 5-16, pl. 3D, figs. 1, 2, 6, 7, and 9; Abelmann, 1990, p. 675 , pl. 5, fig. 13.

Sethocorys sp. Hays, 1965, p. 177, pl. III, fig. 8.

Cystophormis brevispina (Vinassa) Petrushevskaya, 1975, p. 588, pl. 13 , figs. $3-7$, pl. 44 , figs. $1-2$.

Occurrence. middle Eocene to Oligocene, rare to abundant.

Family PLAGONIIDAE Haeckel, emend. Riedel Genus CERATOCYRTIS Bütschli, 1882

Ceratocyrtis spp.

Occurrence. late Eocene to Oligocene, few to common.

Genus CORYTHOMELISSA Campbell, 1951

Corythomelissa horrida Petrushevskaya

(Plate 3, Fig. 14)

Corythomelissa horrida Petrushevskaya, 1975, p. 590, pl. 11, figs. 14-15, pl. 21, fig. 9.

Occurrence. late Eocene to Oligocene, rare to few.

\section{Corythomelissa(?) sp.}

(Plate 2, Figs. 3-4)

Description. The shell is conical and has two segments. The cephalis is hemispherical and has irregularly distributed and sized pores. The surface of the cephalis often is rough or thorny. Collar stricture is distinct. The thorax is conical with irregularly distributed pores, whose sizes and shapes are irregular. Slight longitudinal grooves often exist at the upper part of the thorax. The base of the thorax is closed.

Measurements. Length of shell exclusive of feet is $80-100 \mu \mathrm{m}$; width of shell exclusive of feet is $75-95 \mu \mathrm{m}$, measured in six specimens.

Remarks. Because the cephalis of this species is smaller than that in Corythomelissa horrida Petrushevskaya, this species has been tentatively and questionably assigned to Genus Corythomelissa. The shape of the cephalis is similar to that of Genus Ceratocyrtis rather than Corythomelissa.

Occurrence. Oligocene, rare.

\section{Genus LITHOMELISSA Ehrenberg, 1847}

Lithomelissa challengerae Chen

(Plate 4, Figs. 11-12)

Lithomelissa challengerae Chen, 1975 , p. 457 , pl. 8, fig. 3 .

Occurrence. Oligocene, rare.

\section{Lithomelissa sphaerocephalis Chen}

(Plate 4, Figs. 8-9)

Lithomelissa sphaerocephalis Chen, 1975, p. 457, pl. 8, figs. 1-2.

Occurrence. middle Eocene to late Oligocene, rare to common.

\section{Lithomelissa tricornis Chen}

(Plate 2, Figs. 5-6)

Lithomelissa tricornis Chen, 1975, p. 458, pl. 8, figs. 6-7.

Occurrence. late Eocene to Oligocene, rare.

Lithomelissa sp.

(Plate 2, Figs. 11-12)

Lithomelissa robusta (Chen) Abelmann, 1990, pl. 5, figs. 2A-2B.

Description. See Abelmann (1990).

Remarks. This species differs from $L$. robusta Chen in its robust- ness and the size of its shell, and because it has no distinct threebladed wings and in the shape of the thorax. Abelmann's (1990) forms are similar to this species. This species is characterized by its irregularly perforated spherical cephalis that has a three-bladed apical horn, its distinct collar stricture, and its thoracic shape, of which upper part is conical and lower part is cylindrical, or becomes slightly narrower downward.

Occurrence. late Oligocene, rare to few.

Genus VELLICUCULLUS Riedel and Campbell, 1952

Vellicucullus cf. oddgurneri Bjørklund

(Plate 2, Figs. 7-8)

Vellicucullus oddgurneri Bjørklund,rklund 1976, p. 1126, pl. 19, figs. 6-9.

Vellicucullus cf. oddgurneri (Bjørklund)rklund Abelman, 1990, p. 698, pl. 8, fig. 6 .

Occurrence. late Oligocene, few.

Plagoniid, gen. et sp. indet.

(Plate 1, Fig. 10)

Description. The shell is composed of a cephalis only and is spherical to subspherical in shape. The cephalic wall is usually smooth, with irregularly distributed elliptical pores, of various sizes. A circular or subcircular ring lies at the base of the cephalis, while cephalic skeletal elements are situated below the ring.

Measurements. Length of shell is $75-90 \mu \mathrm{m}$; width of shell is $65-80$ $\mu \mathrm{m}$, measured in six specimens.

Occurrence. Mainly late Oligocene, rare to few.

Family PTEROCORYIDAE Haeckel, emend. Riedel Genus THEOCYRTIS Haeckel, 1887

Theocyrtis tuberosa Riedel

(Plate 6, Figs. 1-2)

Theocyrtis tuberosa Riedel, 1959, p. 298, pl. 2, figs. 10-11; Sanfilippo et al., 1985, pp. 701-702, fig. 32 .

Remarks. T. tuberosa from Hole 748B has longitudinal plicae on its thoracic surface, but no tubercles at all. This character is the same as in the earlier forms of $T$. tuberosa in low and middle latitude areas (Sanfilippo et al., 1985). T. tuberosa appeared within the late Eocene Thyrsocyrtis bromia Zone; it might be a cosmopolitan species at the earlier stage of its phylogeny. This horizon (120-748B-16H-2) may be correlated to the $T$. bromia Zone in low-latitude areas.

Occurrence. Only in Sample 120-748B-16H-2, 45-47 cm, late Eocene, few.

\section{Family THEOPERIDAE Haeckel, emend. Riedel}

Remarks. Takemura (1986) divided Jurassic theoperids into two families (Theoperidae and Arcanicapsidae), based on their cephalic skeletal structures. Although these two cephalic structural types were observed in Cenozoic theoperids, the definition of this family proposed by Riedel $(1967,1971)$ was adopted for this study because of the scarcity of data on cephalic structures of Cenozoic theoperids observed with scanning electron microscopes.

\section{Genus ARCHAEODICTYOMITRA Pessagno, 1976}

Archaeodictyomitra(?) sp.

(Plate 3, Figs. 1-2)

Theoperid, gen. et sp. indet. Johnson, 1974, pl. 3, fig. 12.

Description. The shell is conical to spindle-shaped and somewhat curved, with five or six segments. Almost all the shell surface is covered with longitudinal costae. The cephalis is small, spherical, and poreless. The thorax is conical, with tetragonally arranged circular pores. The abdomen and post-abdominal segments are cylindrical or barrel-shaped, with longitudinally arranged pores. The pores on post-thoracic segments are usually arranged in three transverse lines. The shell becomes widest usually at the fourth segment. Sometimes, slight strictures are observed at joints of segments. The last segment becomes narrower at its base and has an open circular aperture. The costae originated at the thorax and number less than 20 . 
Measurements. Length of shell is $110-155 \mu \mathrm{m}$; width of shell is 65-75 $\mu \mathrm{m}$, measured in five specimens.

Remarks. This species was tentatively assigned to Genus Arachaeodictyomitra Pessagno because Pessagno's $(1976,1977)$ definition of this genus is applicable to this species, although sometimes slight strictures are observed. It is unclear whether this species has a phylogenetic relationship to Mesozoic Aracheodictyomitra or Dictyomitra.

Occurrence. Oligocene, rare.

Genus ARTOSTROBUS Haeckel, 1887

Artostrobus(?) cf. pretabulatus Petrushevskaya (Plate 5, Fig. 12)

cf. Artostrobus(?) pretabulatus Petrushevskaya, 1975, p. 580, pl. 10, figs. 2-3.

Remarks. The shape of the shell of this species for this paper is somewhat wider and more conical compared with that described by Petrushevskaya (1975).

Occurrence. late Eocene, rare.

\section{Genus CALOCYCLAS Ehrenberg, 1847}

\section{Calocyclas cf. semipolita Clark and Campbell}

$$
\text { (Plate 4, Figs. 5-6) }
$$

Calocyclas semipolita Clark and Campbell, 1942, p. 83, pl. 8, figs. 12 , $14,17-19$, and 21-23; Blueford, 1988, p. 246, pl. 2, figs. 4-6.

Calocyclas cf. semipolita (Clark and Campbell) Abelmann, 1990, p. 697 , pl. 7, fig. 4 .

Remarks. This species differs from Cyrtocapsella robusta Abelmann in the size of its shell and the length of its abdomen. The size of the thorax usually is larger than that of $C$. robusta. However, the transition from this species to $C$. robusta is gradual and continuous, and thus distinguishing these two species is sometimes difficult.

Occurrence. Mainly late Eocene to late Oligocene, rare to abundant.

\section{Calocyclas sp. A}

(Plate 1, Figs. 3-4)

Description. The shell is cylindrical with three segments. The cephalis is small, spherical, and poreless, without distinct apical horns. The thorax is large, inflated, and spherical to conical, variously shaped. Thoracic pores are large and usually are longitudinally, or sometimes irregularly, arranged. The abdomen has an open aperture that is usually not longer than the thorax and is cylindrical or barrel-shaped. Abdominal pores are similar to thoracic ones in size, usually longitudinally arranged. Collar and lumber strictures are distinct.

Measurements. Length of shell, exclusive of apical horn, is 150 $200 \mu \mathrm{m}$; width of shell is $100-110 \mu \mathrm{m}$, measured in six specimens.

Remarks. This species is distinguished from Calocyclas cf. semipolita by its inflated thorax and short abdomen. It differs from Calocyclas sp. B of this paper in the inflated shape of its thorax and abdomen, and also differs from Calocyclas sp. $\mathrm{C}$ in having no large apical horns and in the shape of its abdomen. The cephalo-thorax of this species is similar to that of Calocyclas asperum (Ehrenberg), described by Petrushevskaya and Kozlova (1972). However, the abdomen of this species is larger sometimes than that of $C$. asperum.

Occurrence. Mainly late Oligocene, rare to few.

\section{Calocyclas sp. B}

(Plate 5, Fig. 13)

(?)Theocyrtis (Theocorypha) diabloensis (Clark and Campbell) Chen, 1975 , p. 459 , pl. 5, figs. 4-7.

Description. The shell is cylindrical with three segments. The cephalis is small, spherical or hemispherical, and poreless, with a short, thin apical horn. The thorax is inflated and hemispherical with irregularly or longitudinally distributed pores. The collar stricture is distinct. The abdomen is cylindrical or becomes narrower downward. The abdomen has irregularly distributed and variously sized and shaped pores, and has an aperture. The abdomen is usually shorter than the cephalo-thorax. The lumber stricture is visible.

Measurements. Length of shell, exclusive of apical horn, is 135$180 \mu \mathrm{m}$; width of shell is $90-100 \mu \mathrm{m}$, measured in seven specimens.
Remarks. The size of this species is smaller than that of Calocyclas sp. A. This species is similar to some forms of Theocyrtis diabloensis, described by Chen (1975). However, the original illustration of $T$. diabloensis (Campbell and Clark, 1942, pl. 8, fig. 13) clearly differs from this species and forms reported by Chen (1975). Moreover, this species has no pterocoryid-type cephalis. Here, this species was tentatively assigned to the Genus Calocyclas.

Occurrence. middle to late Oligocene, few to common.

$$
\begin{aligned}
& \text { Calocyclas sp. C } \\
& \text { (Plate 7, Figs. 3-4) }
\end{aligned}
$$

(?)Calocyclas semipolita semipolita Clark and Campbell, 1942, pp. 83-84, pl. 8, figs. 12, 14, 17-19, 22, and 23; Blueford, 1988, p. 246, pl. 2, figs. 4-6.

Description. The shell is conically to cylindrically shaped with three segments. The cephalis is small, spherical, and poreless. The apical horn is stout, rodlike, and usually longer than twice the height of the cephalis. The thorax is large, inflated, and hemispherical with longitudinally and hexagonally arranged pores. The collar stricture is distinct. The abdomen is cylindrical and has nearly the same width with thorax. The abdomen has longitudinally or irregularly distributed pores and has an open aperture. In some specimens, the abdomen has a secondary growth of shell and/or small feet. The lumbar stricture is visible.

Measurements. Length of shell, exclusive of apical horn, is 185$220 \mu \mathrm{m}$; length of apical horn is $55-85 \mu \mathrm{m}$; width of shell is $110-130$ $\mu \mathrm{m}$, measured in six specimens.

Remarks. This species is easily distinguished from Calocyclas sp. A and sp. B by the possession of stout, long apical horns. Although this species resembles $C$. semipolita Clark and Campbell, it has a more inflated shell than the latter species.

Occurrence. middle Eocene, common.

\section{Genus CLATHROCYCLAS Haeckel, 1882}

Clathrocyclas universa Clark and Campbell (Plate 7, Fig. 11)

Clathrocyclas universa Clark and Campbell, 1942, p. 86, pl. 7, figs. $8-12,14-21$, and 25 ; Chen, 1975 , p. 459 , pl. 1, figs. 2 and 3 ; Blueford, 1988, pp. 244 and 246 , pl. 2, figs. 1-3.

Occurrence. Eocene, rare to few.

\section{Genus CORNUTELLA Ehrenberg, 1838 Cornutella spp.}

Occurrence. Eocene to Oligocene, rare.

Genus CYCLADOPHORA Ehrenberg, 1847, emend. Lombari and Lazarus, 1988

Cycladophora bicornis (Popofsky)

(Plate 2, Fig. 15)

Pterocorys bicornis Popofsky, 1908, p. 288, pl. 34, figs. 7-8.

Cycladophora bicornis (Popofsky) Lombari and Lazarus, 1988, pp. 106-114, pl. 4, figs. 1-12, pl. 5, figs. 1-12.

Occurrence. late Oligocene, rare.

$$
\text { Cycladophora conica Lombari and Lazarus }
$$

(Plate 2, Figs. 16-17)

Cycladophora conica Lombari and Lazarus, 1988, pp. 105-106, pl. 3, figs. 1-16.

Occurrence. Oligocene, rare to few.

\section{Genus CYCLAMPTERIUM Haeckel, 1887}

$$
\begin{gathered}
\text { Cyclampterium(?) milowi Riedel and Sanfilippo } \\
\text { (Plate 5, Figs. 1-3) }
\end{gathered}
$$

Cyclampterium(?) milowi Riedel and Sanfilippo, 1971, p. 1953, pl. 3B, fig. 3 , pl. 7, figs. $8-9$; Chen, 1975 , p. 460 , pl. 2, figs. 4-5; Abelmann, 1990, p. 696, pl. 7, fig. 8.

Cyclampterium(?) longiventer Chen, 1975 , pp. 459,460 , pl. 10, fig. 7.

Remarks. Chen (1975) described two species of the genus Cyclampterium, C.(?) milowi and C.(?) longiventer. However, it is difficult 
to distinguish these two species. For this study, these forms have been regarded as a single species, C.(?) milowi, following Abelmann (1990).

Occurrence. Eocene to Oligocene, rare in late Oligocene, and few to abundant in Eocene to early Oligocene.

\section{Genus CYRTOCAPSELLA Haeckel, 1887}

Remarks. Sanfilippo and Riedel (1970) defined the Genus Cyrtocapsella as three- or four-segmented theoperids having a very constricted mouth. However, here, this genus name is also used for forms with an open mouth that have a shell structure similar to other Cyrtocapsella.

\section{Cyrtocapsella aff. japonica (Nakaseko)}

(Plate 1, Figs. 11-12)

aff. Cyrtocapsella japonica (Nakaseko) Sanfilippo and Riedel, 1970, p. 452 , pl. 1 , figs. $13-15$.

Description. The shell is similar to $C$. robusta Abelmann, but the abdomen is shorter than the thorax. Abdomen is variously shaped, with large aperture or aperture-fenestrated.

Remarks. This species cannot be distinguished clearly from $C$. robusta Abelmann because variation of the length of abdomen is continuous. Here, this species has been separated from $C$. robusta, based on the length of abdomen.

Occurrence. Oligocene, mainly late Oligocene, rare to common in latest Oligocene.

\section{Cyrtocapsella robusta Abelmann}

(Plate 1, Figs. 5-6)

Cyrtocapsella robusta Abelmann, 1990, p. 696, pl. 5, figs. 10-11.

Remarks. Abelmann (1990) did not describe the state of the aperture of this species. Here, forms having a large aperture also are included in this species. One finds it difficult to make a strict distinction of this species from Cyrtocapsella aff. japonica and Calocyclas cf. semipolita.

Occurrence. Oligocene, few to common.

\section{Genus DICOLOCAPSA Haeckel, 1881}

Dicolocapsa microcephala Haeckel (Plate 4, Figs. 14-15)

Dicolocapsa microcephala Haeckel, 1887, p. 1312, pl. 57, fig. 1; Johnson, 1974, p. 548, pl. 6, fig. 15 .

Occurrence. early Oligocene, rare.

\section{Genus DIPLOCYCLAS Haeckel, 1881}

Remarks. Lombari and Lazarus (1988) regarded this genus as a junior synonym of the genus Cycladophora. Here, this genus name has been tentatively used to describe Diplocyclas sp., following to Petrushevskaya and Kozlova (1972) and Chen (1975), because the taxonomic position of this species is obscure.

\section{Diplocyclas sp.}

(Plate 3, Fig. 16)

Diplocyclas sp. A, Petrushevskaya and Kozlova, 1972, p. 541, pl. 33 , figs. 14-16; Petrushevskaya, 1975 , p. 587 , pl. 24, fig. 4; Chen, 1975 , p. 460 , pl. 7 , figs. $4-5$.

Occurrence. late Eocene to early Oligocene, rare.

\section{Genus EUCYRTIDIUM Ehrenberg, 1847}

\section{Eucyrtidium cheni $\mathrm{n}$. sp.}

(Plate 4, Figs. 1-4)

(?)Eucyrtidium sp. M, Petrushevskaya, 1975, p. 581, pl. 14, fig. 20. Eucyrtidium sp. Chen, 1975 , p. 461, pl. 7, figs. 6-8.

Description. The shell, which has six to eight segments, is conical to spindle shaped, or is conical in the upper part and cylindrical in the lower. The cephalis is small, spherical to hemispherical, and poreless, with an apical horn. This apical horn is conical, three-bladed, and shorter than or nearly the same length as the cephalis. The collar stricture usually is not distinct. The thorax is conical with irregularly distributed pores. The abdomen and post-abdominal segments are usually barrel-shaped or sometimes cylindrical, and commonly has longitudinally distributed pores. Four to six pores are present along a longitudinal line of each segment. Pores on post-thoracic segments usually are uniformly sized, although sometimes distributed irregularly. When segments are barrel-shaped, the strictures are distinct between segments. The shell becomes widest in various portions, usually at the abdomen or post-abdominal segments. The postthoracic segments commonly have nearly the same height. The last segment is usually incomplete.

Measurements. Length of shell, exclusive of apical horn, is 175$270 \mu \mathrm{m}$; width of shell is $90-115 \mu \mathrm{m}$, measured in seven specimens.

Types. Holotype: HUTE-R-4003, Sample 120-748B-12H-7, 45-47 $\mathrm{cm}$ (Plate 4, Figs. 1-2). Paratype: HUTE-R-4004, Sample 120-748B$13 \mathrm{H}-4,45-47 \mathrm{~cm}$ (Plate 4, Figs. 3-4).

Remarks. This species is the same as the Eucyrtidium sp. of Chen (1975), but it contains more variations than the latter. Chen's forms have uniformly barrel-shaped post-thoracic segments. However, many variations exist in the shape of the post-thoracic segments, which are barrel-shaped to cylindrical.

One can hardly distinguish $E$. cheni from $E$. spinosum n. sp. only by the shape of the shell. I could separate these two species only by the length of its apical horn. E. cheni evolved from $E$. spinosum through a process of a shortening of the apical horn during early Oligocene time.

This species is named after Dr. Pei-Hsin Chen for his contribution to Antarctic radiolarian research.

Occurrence. Oligocene; common in early Oligocene and rare to few in late Oligocene.

Eucyrtidium spinosum $\mathrm{n}$. sp.

(Plate 5, Figs. 5-8)

Eucyrtidium sp. A, Petrushevskaya, 1975, p. 581, pl. 14, figs. 21-22.

Description. The shell, which has five to seven segments, is conical to cylindrical, or is conical in the upper part and cylindrical in the lower part. The cephalis is small, spherical to hemispherical, and poreless, with an apical horn. The apical horn is stout, three-bladed, and usually longer than twice the height of the cephalis. The apical horn may become shorter in later specimens. The thorax is conical with irregularly distributed pores. The collar stricture is visible. The abdomen is conical or barrel-shaped, usually with irregularly distributed pores. The lumbar stricture is usually distinct. The post-abdominal segments are barrel-shaped or cylindrical, commonly with longitudinally distributed pores. When segments are barrel-shaped, strictures become distinct between segments. The shell becomes widest at various portions, at the abdomen or post-abdominal segments. The height of each segment varies. Segmentation sometimes becomes irregular.

Measurements. Length of shell, exclusive of apical horn, is 180 $250 \mu \mathrm{m}$; length of apical horn is $30-55 \mu \mathrm{m}$; width of shell is $105-120$ $\mu \mathrm{m}$, measured in 11 specimens.

Types. Holotype: HUTE-R-4005, Sample 120-748B-15H-3, 45-47 $\mathrm{cm}$ (Plate 5, Figs. 7-8), Paratype: HUTE-R-4006, Sample 120-748B14H-6, 45-47 cm (Plate 5, Figs. 5-6).

Remarks. Eucyrtidium spinosum n. sp. differs from Eucyrtidium cheni $\mathrm{n}$. sp. in having an apical horn longer than the height of its cephalis.

Occurrence. late Eocene to early Oligocene, rare to common; rare fragments were found in the late Oligocene section, which may have been reworked from the lower horizon.

\section{Eucyrtidium spp.}

Occurrence. Oligocene, rare.

\section{Genus EUSYRINGIUM Haeckel, 1881}

\section{Eusyringium fistuligerum (Ehrenberg)} (Plate 7, Figs. 5-6)

Eucyrtidium fistuligerum Ehrenberg, 1873, p. 229; 1875, p. 70, pl. 9, fig. 3.

Eusyringium fistuligerum (Ehrenberg) Riedel and Sanfilippo, 1970, p. 527 , pl. 8, figs. 8-9.

Occurrence. Rare in middle Eocene and scattered to rare in late Oligocene. 
Genus LOPHOCONUS Haeckel, 1887

\section{Lophoconus titanothericeraos Clark and Campbell}

(Plate 3, Figs. 12-13)

Lophoconus titanocthericeraos Clark and Campbell, 1942, p. 89, pl. 8, figs. 24-26, 28, and 30-37.

Occurrence. Eocene to Oligocene, rare.

Genus LOPHOCYRTIS Haeckel, 1887

Lophocyrtis biaurita (Ehrenberg)

(Plate 7, Fig. 8)

Eucyrtidium biauritum Ehrenberg, 1873, p. 226; 1875, p. 70, pl. 10, figs. 8-9.

Lophocyrtis biaurita (Ehrenberg) Haeckel, 1887, p. 1411; Chen, 1975, p. 461 , pl. 3, fig. 2 .

Occurrence. Eocene to Oligocene, common to rare.

Genus LYCHNOCANOMA Haeckel, 1887

Remarks. Foreman (1973) used the generic name, Lychnocanoma, for "two-segmented theoperids with three feet, without accompanying ribs in the thorax, and without a large cephalis as Bekoma" (Foreman, 1973, p. 437). Although her definition may be too broad and her selection of this genus name is questionable, the genus Lychnocanoma has been tentatively used for this study.

\section{Lychnocanoma amphitrite Foreman}

(Plate 7, Figs. 9-10)

Lychnocanoma amphitrite Foreman, 1973, p. 437, pl. 11, fig. 10.

Occurrence. Few to abundant in the Eocene, and few to rare in the Oligocene; usually, fragments are found in later samples.

\section{Lychnocanoma cf. babylonis (Clark and Campbell)} (Plate 7, Fig. 13)

Dictyophimus babylonis Clark and Campbell, 1942, p. 67, pl. 9, figs. 32 and 36.

Sethochyrtis babylonis (Clark and Campbell) group, Riedel and Sanfilippo, 1970, p. 528, pl. 9, figs. 1-3.

Lychnocanoma babylonis (Clark and Campbell) group, Foreman, 1973 , p. 437 , pl. 1, fig. 17 , pl. 11, fig. 9 ; Chen, 1975 , p. 462 , pl. 2 , fig. 8 .

Remarks. The aperture of this species apparently is larger than that of $L$. babylonis.

Occurrence. Eocene, rare.

\section{Lychnocanoma conica (Clark and Campbell)}

(Plate 2, Figs. 13-14)

Lychnocanium conicum Clark and Campbell, 1942, p. 71, pl. 9, fig. 38. Lychnocanella conica (Clark and Campbell) Petrushevskaya, 1975, p. 583 , pl. 12 , figs. 2 and $11-15$.

Lychnocanoma sphaerothorax Weaver, 1976, p. 581, pl. 5, figs. 4-5. Lychnocanoma conica (Clark and Campbell) Abelmann, 1990, p. 697 , pl. 6 , fig. 8, pl. 7, figs. 1A-1B.

Remarks. The shape of the thorax of $L$. conica varies from subspherical to truncate-conical. This species is characterized by its relatively large-sized thorax, short apical horn, and in particular, its straight, three-bladed, and short (usually shorter than the thorax) feet, which originate just outside the aperture. Sometimes, this species has a tube (abdomen?) below the thorax, and three feet are never attached to this tube. mon.

Occurrence. late early Oligocene to late Oligocene, few to com-

\section{Lychnocanoma spp.}

Occurrence. Eocene and Oligocene, few.

\section{Genus PERIPYRAMIS Haeckel, 1881}

Peripyramis spp.

Occurrence. Eocene to Oligocene, few.
Genus PTEROCANIUM Ehrenberg, 1847

Pterocanium(?) sp.

(Plate 1, Fig. 7)

Pterocanium sp. (Benson) Chen, 1975, pl. 13, fig. 9.

Occurrence. Eocene to Oligocene, rare to few.

Genus SETHOCYRTIS Haeckel, 1887

Remarks. Riedel (1971) assigned this genus to the Family Pterocoryidae. Chen (1975) described Sethocyrtis sp. (see below) under the Family Pterocoryidae. However, the cephalic structure of Pterocoryidae, lobed cephalis by arches AL, was not observed in Sethocyrtis $\mathrm{sp}$. For this study, Sethocyrtis sp. have been tentatively included within the Family Theoperidae.

Sethocyrtis sp.

(Plate 7, Figs. 14-15)

Sethocyrtis sp. Chen, 1975, p. 459, pl. 1, figs. 4-5.

Remarks. The cephalis of this species is spherical, small, poreless, and similar to those of the Family Theoperidae. This species has a stout shell with a distinct shape. It should be an important species in the Antarctic middle Eocene assemblage.

Occurrence. Common in the middle Eocene and scattered or rare in the Oligocene; Oligocene specimens usually occur as fragments and thus may be reworked.

Theoperid gen. et sp. indet.

(Plate 4, Fig. 10)

Description. The shell has three segments and is conical in its upper part and cylindrical in the lower part. The cephalis is small, subspherical, and usually poreless, with a small, thin apical horn. The thorax is conical and divided into two parts. The upper part of the thorax is subcylindrical or conical, with irregularly distributed pores. Collar stricture is usually indistinct. The lower part of the thorax is inflated and barrel-shaped, with hexagonally and longitudinally arranged, subcircular and relatively large pores. The lumbar stricture is distinct. The abdomen is cylindrical and has irregularly distributed subcircular pores, which are slightly larger than the pores of the lower part of its thorax. Commonly, the upper part of the abdomen is somewhat inflated. The aperture is large.

Measurements. Length of shell is $95-145 \mu \mathrm{m}$; width of shell is 65-80 $\mu \mathrm{m}$, measured in five specimens.

Remarks. This species differs from the species of Genus Calocyclas in the shape of its thorax.

Occurrence. Oligocene, rare to common.

A species list in alphabetical order is shown in Table 4.

\section{ACKNOWLEDGMENTS}

The author thanks Akira Tokuyama of Hyogo University of Teacher Education for his valuable advice for this study. I also thank Toshiharu Nishimura of the same university for his kind advice and assistance. I am grateful to Toyosaburo Sakai of Utsunomiya University and to David Lazarus of ETH Zürich for their valuable advice for this study. I thank the Inoue Foundation for Science for its financial support for my participation during Leg 120 . This study was supported in part by Grants-in-Aid for Scientific Research of Ministry of Education of Japan (Nos. 62790185/Takemura and 01304008/Mizutani).

\section{REFERENCES}

Abelmann, A., 1990. Oligocene to middle Miocene radiolarian stratigraphy of southern high latitudes from Leg 113, Sites 689 and 690, Maud Rise. In Barker, P. F., Kennett, J. P., et al., Proc. ODP, Sci. Results, 113: College Station, TX (Ocean Drilling Program), 675-708.

Barker, P. F., Kennett, J. P., et al., 1988. Proc. ODP, Init. Repts., 113: College Station, TX (Ocean Drilling Program).

Barron, J., Larsen, B., et al., 1989. Proc. ODP, Init. Repts., 119: College Station, TX (Ocean Drilling Program). 
Berggren, W. A., Kent, D. V., and Flynn, J. J., 1985. Jurassic to Paleogene: Part 2, Paleogene geochronology and chronostratigraphy. In Snelling, N. J. (Ed.), The Chronology of the Geological Record. Geol. Soc. Mem. London, 10:141-195.

Bjørklund, K. R., 1976. Radiolaria from the Norwegian Sea, Leg 38 of the Deep Sea Drilling Project. In Talwani, M., Udintsev, G., et al., Init. Repts. DSDP, 38: Washington (U.S. Govt. Printing Office), $1101-1168$.

Blueford, J., 1988. Radiolarian biostratigraphy of siliceous Eocene deposits in central California. Micropaleontology, 34:236-258.

Bütschli, O., 1882. Beiträge zur Kenntnis der Radiolarienskelette, insbesondere der der Cyrtida. Zeitschr. Wiss. Zool., Leipzig, 36:485-540.

Campbell, A. S., 1951. New genera and subgenera of radiolaria. $J$. Paleontol., 25:527-530.

Chen, P. H., 1975. Antarctic radiolaria. In Hayes, D. E., Frakes, L. A., et al., Init. Repts. DSDP, 28: Washington (U.S. Govt. Printing Office), 437-513.

Ciesielski, P. F., Kristoffersen, Y., et al., 1988. Proc. ODP, Init. Repts., 114: College Station, TX (Ocean Drilling Program).

Clark, B. L., and Campbell, A. S., 1942. Eocene radiolarian faunas from the Mt. Diablo area, California. Geol. Soc. Am., Spec. Pap., 39:1-112.

Dreyer, F., 1889. Morphologische Radiolarienstudien, 1. Die Pylombildungen in vergleichend-anatomischer und antwicklungsgeschichllicher Beziehung bei Radiolaria und bei Protisten überhaupt, nebst System und Beschreibung neuer und der bis jetzt bekannten pylomatischen Spumellarien. Jena. Zeit. Naturw., 23:1-138.

Dumitrica, P., 1973. Paleocene radiolaria, DSDP Leg 21. In Burns, R. E., Andrews, J. E., et al., Init. Repts. DSDP, 21: Washington (U.S. Govt. Printing Office), 787-817.

Ehrenberg, C. G., 1847. Uber die mikroskopischen kieselschaligen Polycystinen als mächtige Gebirgsmasse von Barbados und über das Verhältniss der aus mehr als 300 neuen Arten bestehenden ganz eigenthümlichen Formengruppe jener Felsmasse zu den jetzt lebenden Thieren und zur Kreidebildung. Eine neue Anregung zur Erforschung des Erdlebens. Monatsr. Kgl. Preuss. Akad. Wiss. Berlin, 1847:40-60.

1854. Mikrogeologie: Leipzig (Leopold Voss).

1873. Grössere Felsproben des Polycystinen-Mergels von Barbados mit weiteren Erlauterungen. Monats. Kgl. Preuss. Akad. Wiss. Berlin, 1873:213-263.

1875. Fortsetzung der mikrogeologischen Studien als Gesammt-Uebersicht der mikroskopischen Paläontologie gleichartig analysirter Gebirgsarten der Erde, mit specieller Rücksicht auf den Polycystinen-Mergel von Barbados. Abh.. Kgl. Preuss. Akad. Wiss. Berlin, 1875:1-225.

Foreman, H. P., 1966. Two Cretaceous radiolarian genera. Micropaleontology, 12:355-359.

1968. Upper Maestrichtian radiolaria of California. Spec. Pap., Paleontol. (London), 3:1-82.

, 1973. Radiolaria of Leg 10 with systematics and ranges for the families Amphipyndacidae, Artostrobiidae, and Theoperidae. In Worzel, J. L., Bryant, W., et al., Init. Repts. DSDP, 10: Washington (U.S. Govt. Printing Office), 407-474.

Goll, R. M., 1968. Classification and phylogeny of Cenozoic Trissocyclidae (radiolaria) in the Pacific and Caribbean basins. Part I. J. Paleontol., 42:1409-1432.

1978. Five trissocyclid radiolaria from Site 338. In Talwani, M., Udintsev, G., et al., Init. Repts. DSDP, suppl. to Vols. 38, 39, 40, and 41: Washington (U.S. Govt. Printing Office), 177-191.

Haeckel, E., 1862. Die Radiolarien (Rhizopoda Radiolaria): Berlin (Reimar),

1881. Entwurf eines Raiolarien-Systems auf Grund von Studien der Challenger-Radiolarien. Jena. Zeits. Naturw., 15:418-472.

1887. Report on the radiolaria collected by H.M.S. Challenger during the years 1873-1876. Rept. Sci. Results Voy. H.M.S. Challenger, Zool., 18:1-1803.

Hays, J. D., 1965. Radiolaria and late Tertiary and Quaternary history of Antarctic Seas. Biol. Antarctic Seas II, Antarctic Res. Ser., 5:125-184.

Johnson, D. A., 1974. Radiolaria from the East Indian Ocean, DSDP Leg 22. In von der Borch, C. C., Sclater, J. G., et al., Init. Repts. DSDP, 22: Washington (U.S. Govt. Printing Office), 521-575.
Kling, S. A., 1973. Radiolaria from the eastern North Pacific, Deep Sea Drilling Project Leg 18. In Kulm, L. D., von Huene, R., et al., Init. Repts. DSDP, 18: Washington (U.S. Govt. Printing Office), 617-671.

Lombari, G., and Lazarus, D. B., 1988. Neogene cycladophorid radiolarians from North Atlantic, Antarctic, and North Pacific deep-sea sediments. Micropaleontology, 34:97-135.

Nigrini, C., 1977. Tropical Cenozoic Artostrobiidae (radiolaria). Micropaleontology, 23:241-269.

Pessagno, E. A., Jr., 1976. Radiolarian zonation and stratigraphy of the Upper Cretaceous portion of the Great Valley Sequence, California Coast Ranges. Micropaleontol. Spec. Publ., 2:1-95.

1977. Lower Cretaceous radiolarian biostratigraphy of the Great Valley Sequence and Franciscan Complex, California Coast Ranges. Cushman Found. Foraminiferal Res., Spec. Publ., 15:187.

Petrushevskaya, M. G., 1971. Radiolarians of the oceans. Expl. Fauna Seas IX, XVII:3-417.

1975. Cenozoic radiolarians of the Antarctic, Leg 29, DSDP. In Kennett, J. P., Houtz, R. E., et al., Init. Repts. DSDP, 29: Washington (U.S. Govt. Printing Office), 541-675.

Petrushevskaya, M. G., and Kozlova, G. E., 1972. Radiolaria: Leg 14, Deep Sea Drilling Project. In Hayes, D. E., Pimm, A. C., et al., Init. Repts. DSDP, 14: Washington (U.S. Govt. Printing Office), 495-648.

Popofsky, A., 1908. Die Radiolarien der Antarktis (mit Ausnahme der Tripyleen). Deuts. Südpolar Exped. (1901-1903), Zool Vol. 2, 10:183-305.

, 1912. Die Sphaerelarien des warmwassergebietes. Deuts. Südpolar Exped. (1901-1913) Zool. Vol. 5, 13:73-160.

Riedel, W. R., 1959. Oligocene and lower Miocene radiolaria in tropical Pacific sediments. Micropaleontology, 5:285-302. , 1967. Protozoa (subclass radiolaria). In Harland, W. B., et al. (Eds.), The Fossil Record. Geol. Soc. London, 291-298.

1971. Systematic classification of polycyctine radiolaria. In Funnel, B. M., and Riedel, W. R. (Eds.), The Micropaleontology of Oceans: Cambridge (Cambridge Univ. Press), 649-661.

Riedel, W. R., and Campbell, A. S., 1952. A new Eocene radiolarian genus. J. Paleontol., 26:667-669.

Riedel, W. R., and Sanfilippo, A., 1970. Radiolaria, Leg 4, Deep Sea Drilling Project. In Bader, R. G., Gerard, R. D., et al., Init. Repts. DSDP, 4: Washington (U.S. Govt. Printing Office), 503-575. 1971. Cenozoic radiolaria from the western tropical Pacific, Leg 7. In Winterer, E. L., Riedel, W. R., et al., Init. Repts. DSDP, 7, Pt. 2: Washington (U.S. Govt. Printing Office), 1529-1672. 1978. Stratigraphy and evolution of tropical Cenozoic radiolarians. Micropaleontology, 23:61-96.

Sanfilippo, A., and Riedel, W. R., 1970. Post-Eocene "closed" theoperid radiolarians. Micropaleontology, 16:446-462.

1973. Cenozoic radiolaria (exclusive of theoperids, artostrobiids and amphipyndacids) from the Gulf of Mexico, DSDP Leg 10. In Worzel, J. L., Bryant, W., et al., Init. Repts. DSDP, 10: Washington (U.S. Govt. Printing Office), 475-611.

Sanfilippo, A., Westberg-Smith, M. J., and Riedel, W. R., 1985. Cenozoic radiolaria. In Bolli, H. M., Saunders, J. B., and PerchNielsen, K. (Eds.), Plankton Stratigraphy: Cambridge (Cambridge Univ. Press), 631-712.

Schlich, R., Wise, S. W., Jr., et al., 1989. Proc. ODP, Init. Repts., 120: College Station, TX (Ocean Drilling Program).

Takemura, A., 1986. Classification of Jurassic nassellarians (radiolaria). Palaeontographica, Abt. A, 195:29-74.

Weaver, F. M., 1976. Antarctic radiolaria from the southeast Pacific Basin, DSDP Leg 35. In Hollister, C. D., Craddock, C. et al., Init. Repts. DSDP, 35: Washington (U.S. Govt. Printing Office), 569-603. , 1983. Cenozoic radiolarians from the southwest Atlantic, Falkland Plateau region, Deep Sea Drilling Project Leg 71. In Ludwig, W. J., Krasheninnikov, V. A., et al., Init. Repts. DSDP, 71, Pt. 2: Washington (U.S. Govt. Printing Office), 667-686.

Date of initial receipt: 19 February 1990

Date of acceptance: 25 October 1990

Ms 120B-177 
Table 4. List of species in alphabetical order.

Species Name species No. Plate Figure page

Amphipyndax stocki (Campbell and Clark) Amphistylus angelinus (Clark and Campbell) Amphistylus(?) sp. Archaeodictyomitra(?) sp. Artostrobus(?) cf. pretabulatus Petrushevskaya Axoprunum bispiculum (Popofsky) Axoprunum pierinae (Clark and Campbell) Axoprunum(?) irregularis, n. sp.

Botryopyle dictyocephalus Haeckel Calocyclas cf. semipolita Clark and Campbell

Calocyclas sp. A

Calocyclas sp. B

Calocyclas sp. C

Carpocanistrum spp.

Clathrocyclas universa Clark and Campbell

Corythomelissa horrida Petrushevskaya

Corythomelissa(?) sp.

Corythospyris aff. jubata Gol

Cycladophora bicornis (Popofsky)

Cycladophora conica Lombari and Lazarus

Cyclampterium(?) milowi Riedel and Sanfilippo

Cyrtocapsella aff. japonica (Nakaseko)

Cyrtocapsella robusta Abelmann

Dendrospyris stabilis Goll

Dicolocapsa microcephala Haeckel

Dictyoprora mongolfieri (Ehrenberg)

Dictyoprora pirum (Ehrenberg)

Diplocyclas sp.

Eucyrtidium cheni, n. sp.

Eucyrtidium spinosum, n. sp.

Eusyringium fistuligerum (Ehrenberg)

Heliostylus sp.

Lithapium anoectum Riedel and Sanfilippo

Lithapium cf. mitra (Ehrenberg)

Lithomelissa challengerae Chen

Lithomelissa sp.

Lithomelissa sphaerocephalus Chen

Lithomelissa tricornis Chen

Lophoconus titanothericeraos Clark and Campbell

Lophocyrtis biaurita (Ehrenberg)

Lychnocanoma amphitrite Foreman

Lychnocanoma cf. babylonis (Clark and Campbell)

Lychnocanoma conica (Clark and Campbell)

Periphaena decora Ehrenberg

Periphaena heliasteriscus (Clark and Campbell)

Plagoniid gen. et sp. indet.

Prunopyle haysi Chen

Prunopyle tetrapila Hays

Pterocanium(?) sp.

Sethocyrtis sp.

Siphocampe acephala (Ehrenberg)

Siphocampe nodosaria (Haeckel)

Siphocampe(?) quadrata (Petrushevskaya and Kozlova)

Spongoplegma aff. antarcticum Haeckel

Theocyrtis tuberosa Riedel

Theoperid, gen. et sp. indet.

Vellicucullus cf. oddgurneri Bjørklund

Zygocircus bütchli Haeckel

\begin{tabular}{|c|c|c|c|c|}
\hline & & & & \\
\hline $\mathrm{N}$ & 4 & 6 & 10,11 & $x$ \\
\hline S & 1 & 1 & 8,9 & $x$ \\
\hline S & 2 & 5 & 9,10 & $x$ \\
\hline $\mathrm{N}$ & 22 & 3 & 1,2 & $x$ \\
\hline $\mathrm{N}$ & 23 & 5 & 12 & $x$ \\
\hline S & 3 & 1 & 1,2 & $x$ \\
\hline S & 4 & 6 & $3 \sim 6$ & $x$ \\
\hline$S$ & 5 & 3 & $8 \sim 11$ & $x$ \\
\hline $\mathrm{N}$ & 10 & 3 & 7 & $x$ \\
\hline $\mathrm{N}$ & 24 & 4 & 5,6 & $x$ \\
\hline $\mathrm{N}$ & 25 & 1 & 3,4 & $x$ \\
\hline $\mathrm{N}$ & 26 & 5 & 13 & $x$ \\
\hline $\mathrm{N}$ & 27 & 7 & 3,4 & $x$ \\
\hline $\mathrm{N}$ & 11 & 3 & 5,6 & $x$ \\
\hline $\mathrm{N}$ & 28 & 7 & 11 & $x$ \\
\hline $\mathrm{N}$ & 13 & 3 & 14 & $x$ \\
\hline $\mathrm{N}$ & 14 & 2 & 3,4 & $x$ \\
\hline $\mathrm{N}$ & 1 & 3 & 3,4 & $x$ \\
\hline $\mathrm{N}$ & 30 & 2 & 15 & $x$ \\
\hline $\mathrm{N}$ & 31 & 2 & 16,17 & $x$ \\
\hline $\mathrm{N}$ & 32 & 5 & $1 \sim 3$ & $x$ \\
\hline $\mathrm{N}$ & 34 & 1 & 11,12 & $x$ \\
\hline $\mathrm{N}$ & 33 & 1 & 5,6 & $x$ \\
\hline $\mathrm{N}$ & 2 & 4 & 7 & $x$ \\
\hline $\mathrm{N}$ & 35 & 4 & 14,15 & $x$ \\
\hline$N$ & 5 & 7 & 12 & $x$ \\
\hline $\mathrm{N}$ & 6 & 5 & 11 & $x$ \\
\hline $\mathrm{N}$ & 36 & 3 & 16 & $x$ \\
\hline $\mathrm{N}$ & 37 & 4 & $1 \sim 4$ & $x$ \\
\hline $\mathrm{N}$ & 38 & 5 & $5 \sim 8$ & $x$ \\
\hline $\mathrm{N}$ & 40 & 7 & 5,6 & $x$ \\
\hline$S$ & 14 & 6 & 7 & $x$ \\
\hline$S$ & 6 & 7 & 1 & $x$ \\
\hline $\mathrm{S}$ & 7 & 7 & 2 & $x$ \\
\hline$N$ & 15 & 4 & 11,12 & $x$ \\
\hline $\mathrm{N}$ & 18 & 2 & 11,12 & $x$ \\
\hline $\mathrm{N}$ & 16 & 4 & 8,9 & $x$ \\
\hline $\mathrm{N}$ & 17 & 2 & 5,6 & $x$ \\
\hline $\mathrm{N}$ & 41 & 3 & 12,13 & $x$ \\
\hline $\mathrm{N}$ & 42 & 7 & 8 & $x$ \\
\hline $\mathrm{N}$ & 43 & 7 & 9,10 & $x$ \\
\hline $\mathrm{N}$ & 44 & 7 & 13 & $x$ \\
\hline $\mathrm{N}$ & 45 & 2 & 13,14 & $x$ \\
\hline$S$ & 15 & 6 & 8 & $x$ \\
\hline$S$ & 16 & 4 & 13 & $x$ \\
\hline $\mathrm{N}$ & 20 & 1 & 10 & $x$ \\
\hline S & 9 & 1 & 13,14 & $x$ \\
\hline$S$ & 10 & 2 & 1,2 & $x$ \\
\hline $\mathrm{N}$ & 48 & 1 & 7 & $x$ \\
\hline $\mathrm{N}$ & 49 & 7 & 14,15 & $x$ \\
\hline$N$ & 7 & 6 & 9 & $x$ \\
\hline $\mathrm{N}$ & 8 & 3 & 15 & $x$ \\
\hline $\mathrm{N}$ & 9 & 7 & 7 & $x$ \\
\hline$S$ & 12 & 2 & 9,10 & $x$ \\
\hline $\mathrm{N}$ & 21 & 6 & 1,2 & $x$ \\
\hline $\mathrm{N}$ & 50 & 4 & 10 & $x$ \\
\hline$N$ & 19 & 2 & 7,8 & $x$ \\
\hline $\mathrm{N}$ & 3 & 5 & 4 & $x$ \\
\hline
\end{tabular}

Note: Species no. indicates the number in Tables 1 and 2. 


\section{A. TAKEMURA}
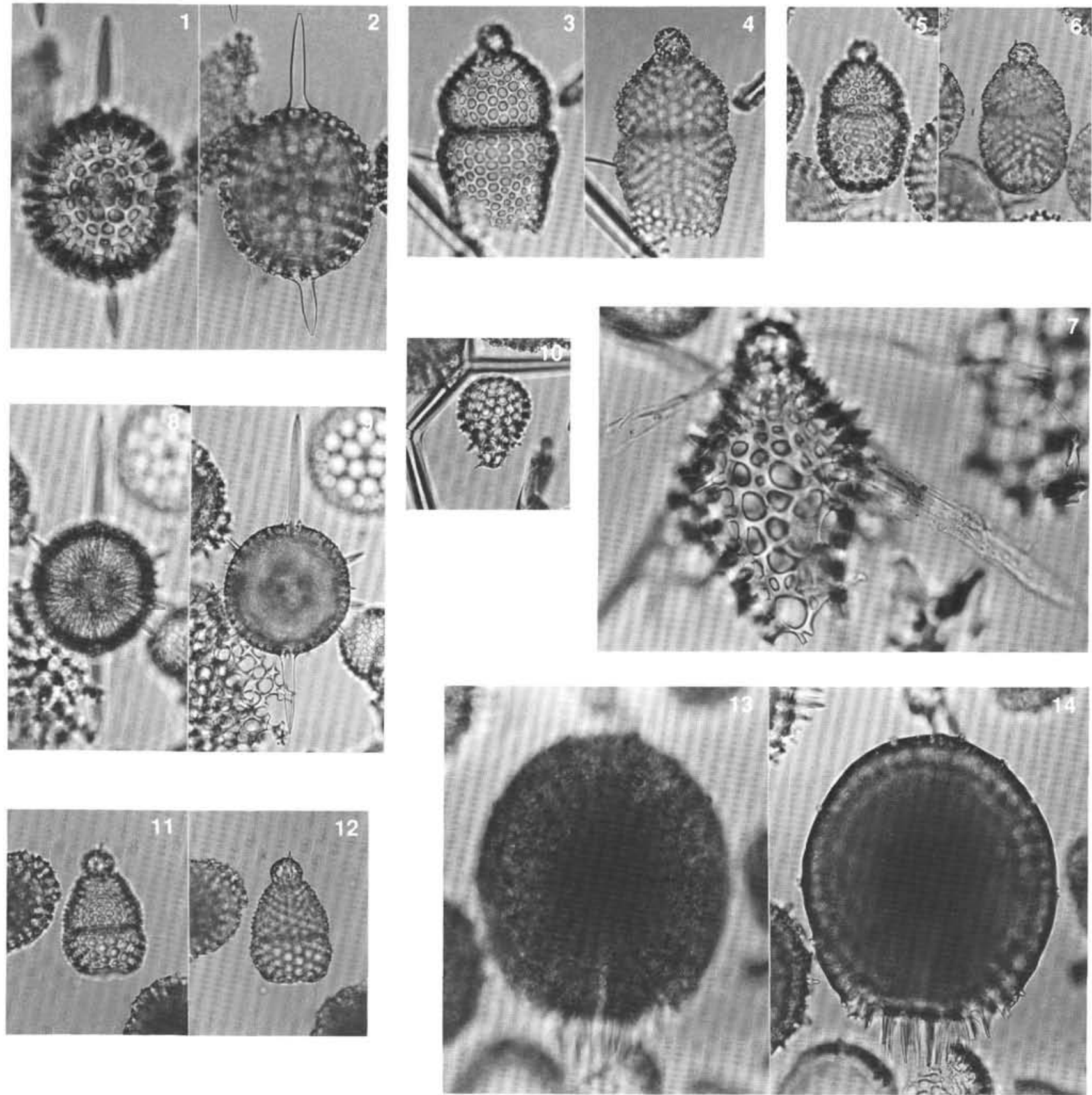

Plate 1. 1, 2. Axoprunum bispiculum (Popofsky), Sample 120-748B-9H-1, $45-47 \mathrm{~cm} .3$, 4. Calocyclas sp. A, Sample 120-748B-9H-1, 45-47 cm. 5, 6. Cyrtocapsella robusta Abelmann, Sample 120-748B-9H-1, $45-47 \mathrm{~cm}$. 7. Pterocanium(?) sp., Sample 120-748B-9H-1, 45-47 cm. 8, 9. Amphistylus angelinus (Clark and Campbell), Sample 120-748B-9H-2, $45-47 \mathrm{~cm}$. 10. Plagoniid gen. et sp. indet., Sample 120-748B-9H-2, 45-47 cm. 11, 12. Cyrtocapsella aff. japonica (Nakaseko), Sample 120-748B-9H-2, $45-47 \mathrm{~cm}$. 13, 14. Prunopyle haysi Chen, Sample $120-748 \mathrm{~B}-9 \mathrm{H}-3,45-47 \mathrm{~cm}$. Magnification of all figures is $175 \times$. 

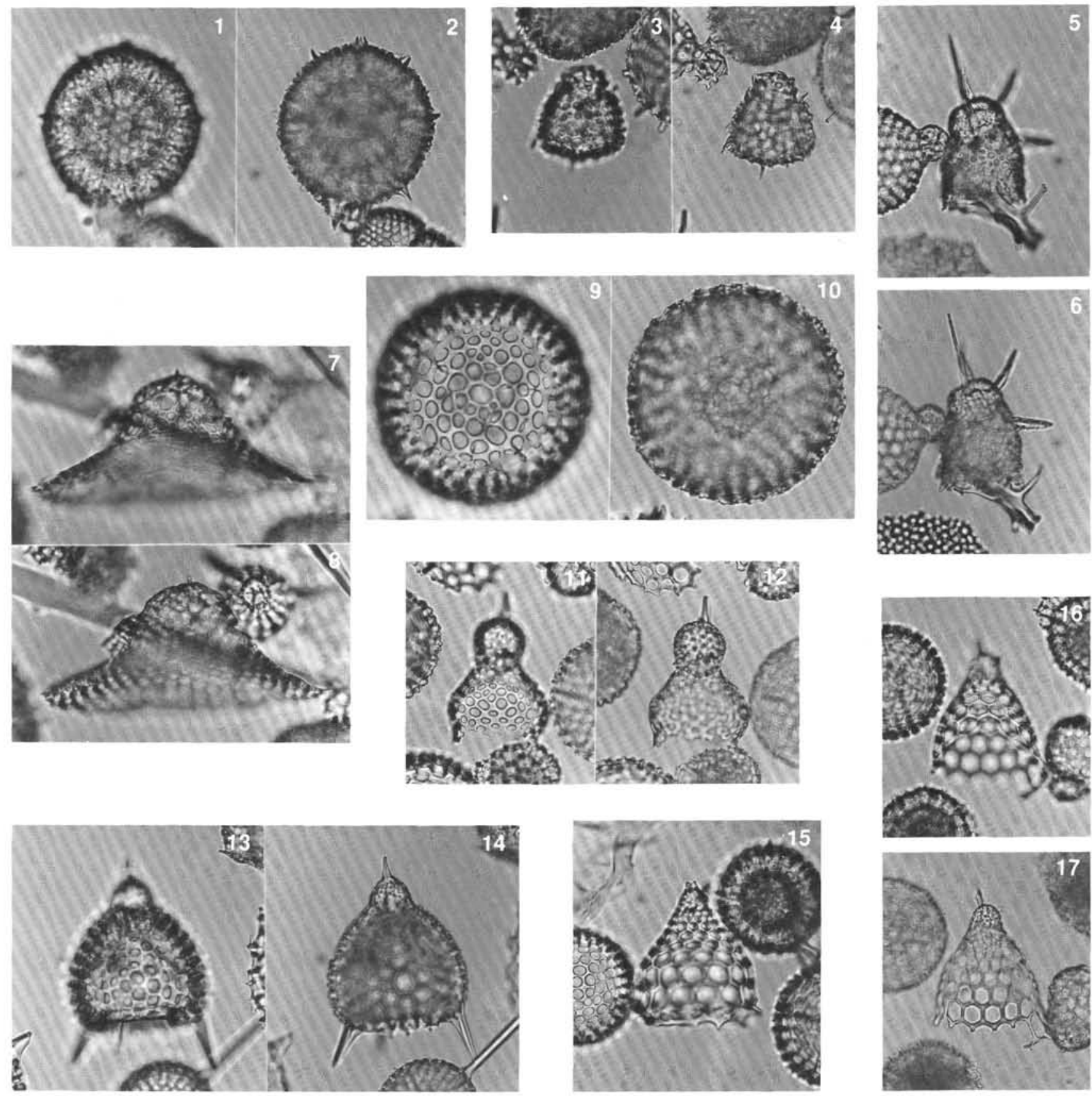

Plate 2. 1, 2. Prunopyle tetrapila Hays, Sample 120-748B-9H-3, $45-47 \mathrm{~cm} .3,4$. Corythomelissa(?) sp., Sample 120-748B-9H-3, 45-47 cm. 5, 6. Lithomelissa tricornis Chen, Sample 120-748B-9H-3, $45-47 \mathrm{~cm}$. 7, 8. Vellicucullus cf. oddgurneri Bjørklund,rklund Sample 120-748B-9H-3, 45-47 cm. 9, 10. Spongoplegma aff. antarcticum Haeckel, Sample 120-748B-9H-4, $45-47 \mathrm{~cm}$. 11, 12. Lithomelissa sp., Sample 120-748B-9H-4, 45-47 cm. 13, 14. Lychnocanoma conica (Clark and Campbell), Sample 120-748B-9H-4, 45-47 cm. 15. Cycladophora bicornis (Popofsky), Sample 120-748B-10H-2, 45-47 cm. 16, 17. Cycladophora conica Lombari and Lazarus, Sample $120-748 \mathrm{~B}-10 \mathrm{H}-2,45-47 \mathrm{~cm}$. Magnification of all figures is $175 \times$. 

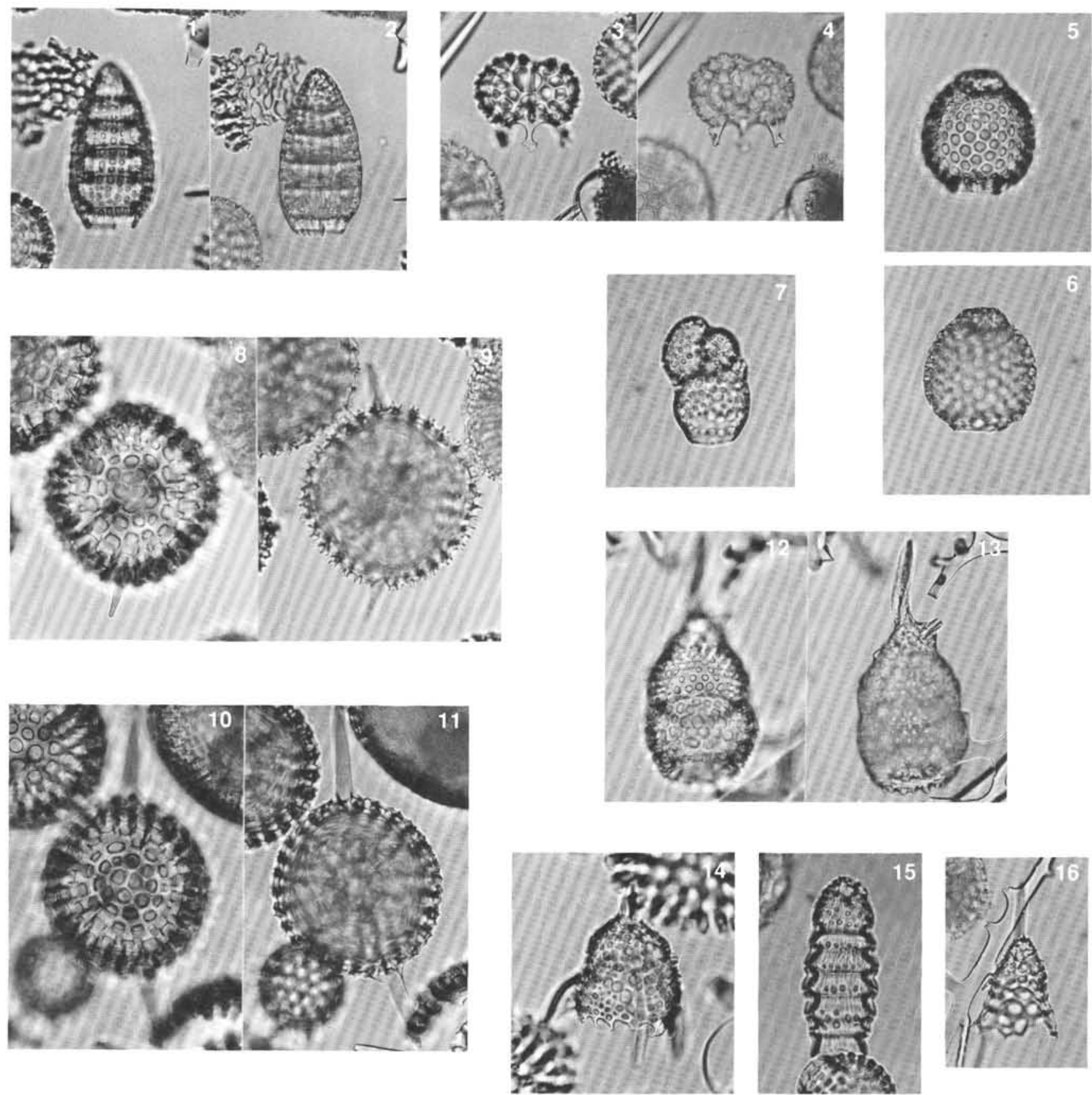

Plate 3. 1, 2. Archaeodictyomitra(?) sp., Sample 120-748B-10H-5, 45-47 cm. 3, 4. Corythospyris aff. jubata Goll, Sample 120-748B-11H-4, $45-47 \mathrm{~cm} .5$, 6. Carpocanistrum spp., Sample 120-748B-11H-4, 45-47 cm. 7. Botryopyle dictyocephalus Haeckel, Sample 120-748B-11H-4, $45-47 \mathrm{~cm} .8-11$. Axoprunum(?) irregularis n. sp.; $(8,9)$ holotype, HUTE-R-4001, Sample 120-748B-11H-4, 45-47 cm; (10, 11$)$ paratype, HUTE-R-4002, Sample 120-748B-12H-7, 45-47 cm. 12, 13. Lophoconus titanothericeraos Clark and Campbell, Sample 120-748B-11H-4, $45-47 \mathrm{~cm}$. 14. Corythomelissa horrida Petrushevskaya, Sample 120-748B-11H-6, $45-47 \mathrm{~cm}$. 15. Siphocampe nodosaria (Haeckel), Sample $120-748 \mathrm{~B}-11 \mathrm{H}-7,45-47 \mathrm{~cm}$. 16. Diplocyclas sp., Sample 120-748B-12H-5, $45-47 \mathrm{~cm}$. Magnification of all figures is $175 \times$. 

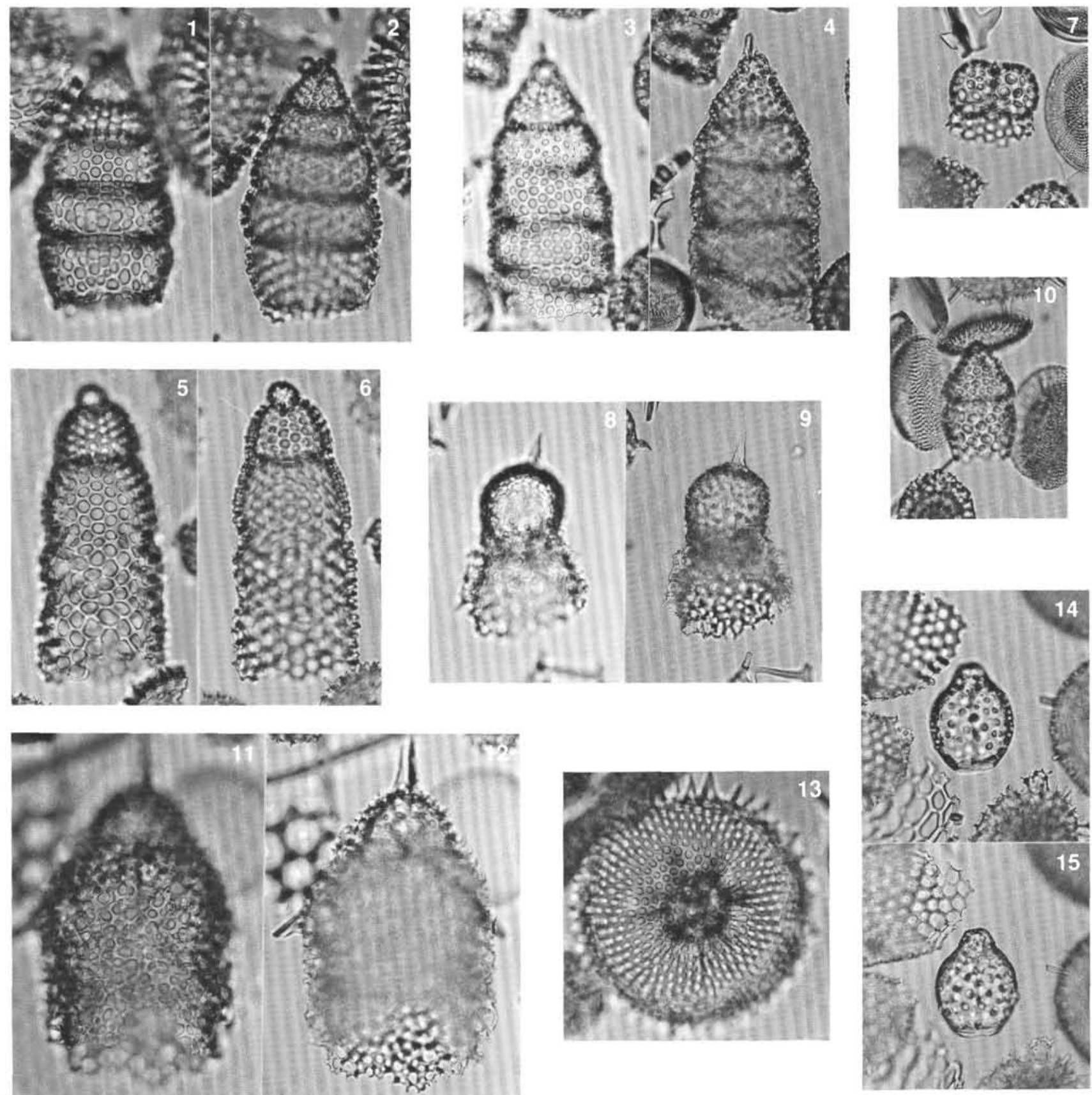

Plate 4. 1-4. Eucyrtidium cheni $\mathrm{n}$. sp.; (1, 2) holotype, HUTE-R-4003, Sample 120-748B-12H-7, $45-47 \mathrm{~cm}$; $(3,4)$ paratype, HUTE-R-4004, Sample 120-748B-13H-4, $45-47 \mathrm{~cm}$. 5, 6. Calocyclas cf. semipolita Clark and Campbell, Sample 120-748B-13H-3, 45-47 cm. 7. Dendrospyris stabilis Goll, Sample 120-748B-13H-4, 45-47 cm. 8, 9. Lithomelissa sphaerocephalis Chen, Sample 120-748B-13H-4, 45-47 $\mathrm{cm}$. 10. Theoperid gen. et sp. indet., Sample 120-748B-13H-4, 45-47 cm. 11, 12. Lithomelissa challengerae Chen, Sample 120-748B-14H-1, $45-47 \mathrm{~cm}$. 13. Periphaena heliasteriscus (Clark and Campbell), Sample 120-748B-14H-1, 45-47 cm. 14, 15. Dicolocapsa microcephala Haeckel, Sample 120-748B-13H-6, 45-47 cm. Magnification of all figures is $175 \times$. 

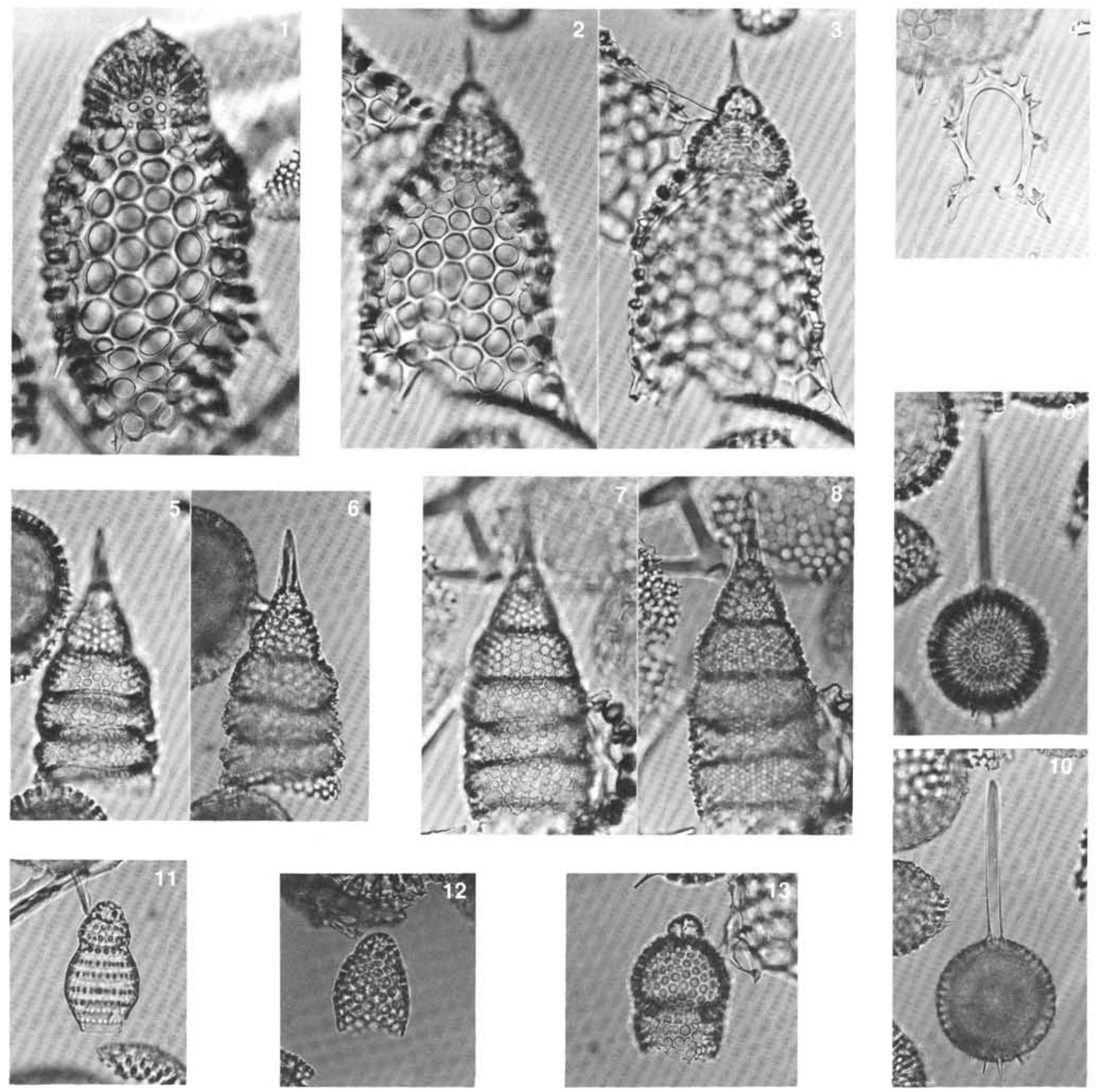

Plate 5. 1-3. Cyclampterium(?) milowi Riedel and Sanfilippo; (1) Sample 120-748B-14H-4, 45-47 cm; (2-3) Sample 120-748B-19H-4, 45-47 cm. 4. Zygocircus bütchli Haeckel, Sample 120-748B-14H-6, $45-47 \mathrm{~cm} .5-8$. Eucyrtidium spinosum n. sp.; $(5,6)$ paratype, HUTE-R-4006, Sample 120-748B-14H-6, 45-47 cm; (7, 8) holotype, HUTE-R-4005, Sample 120-748B-15H-3, 45-47 cm. 9, 10. Amphistylus(?) sp., Sample 120-748B-15H-1, 45-47 cm. 11. Dictyoprora pirum (Ehrenberg), Sample 120-748B-15H-2, 45-47 cm. 12. Artostrobus(?) cf. pretabulatus Petrushevskaya, Sample 120-748B-15H-3, 45-47 cm. 13. Calocyclas sp. B, Sample 120-748B-16H-1, $45-47 \mathrm{~cm}$. Magnification of all figures is $175 \times$. 

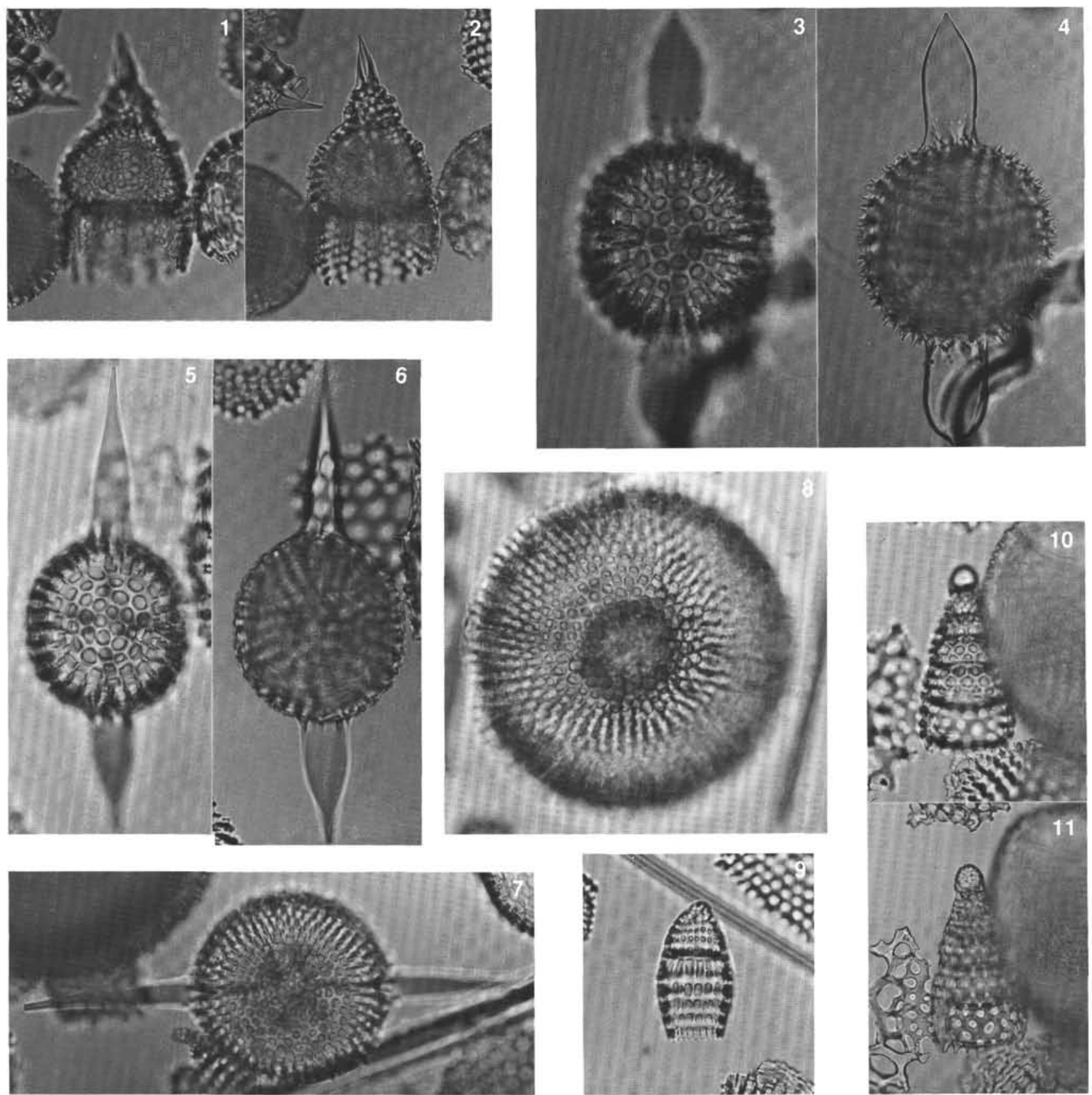

Plate 6. 1, 2. Theocyrtis tuberosa Riedel, Sample 120-748B-16H-2, 45-47 cm. 3-6. Axoprunum pierinae (Clark and Campbell); $(3,4)$ Sample 120-748B-16H-4, 45-47 cm; (5, 6) Sample 120-748B-17H-4, 45-47 cm. 7. Heliostylus sp., Sample 120-748B-17H-4, 45-47 cm. 8. Periphaena decora Ehrenberg, Sample 120-748B-17H-4, 45-47 cm. 9. Siphocampe acephala (Ehrenberg), Sample 120-748B-17H-7, 45-47 cm. 10, 11. Amphipyndax stocki (Campbell and Clark), Sample 120-748B-18H-7, 45-47 cm. Magnification of all figures is $175 \times$. 

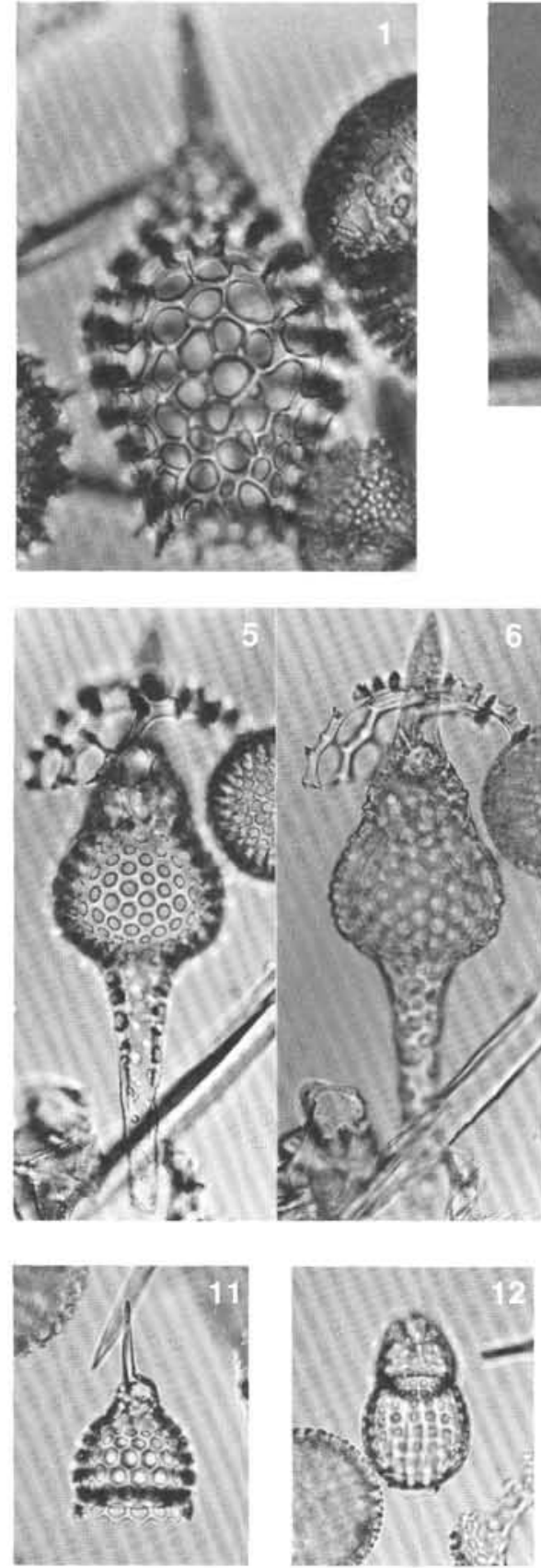
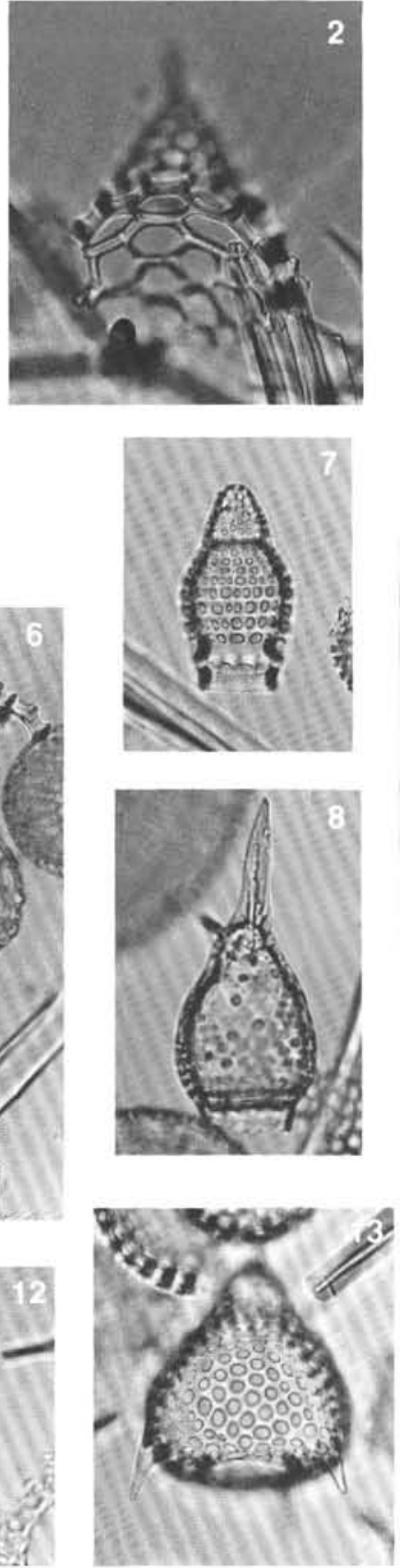

Plate 7. 1. Lithapium anoectum Riedel and Sanfilippo, Sample 120-748B-19H-4, 45-47 cm. 2. Lithapium mitra (Ehrenberg), Sample 120-748B-19H-4, 45-47 cm. 3, 4. Calocyclas sp. C, Sample 120-748B-19H-4, 45-47 cm. 5, 6. Eusyringium fistuligerum (Ehrenberg), Sample 120-748B-19H-4, 45-47 cm. 7. Siphocampe(?) quadrata (Petrushevskaya and Kozlova), Sample 120-748B-19H-4, 45-47 cm. 8. Lophocyrtis biaurita (Ehrenberg), Sample 120-748B-19H-4, 45-47 cm. 9, 10. Lychnocanoma amphitrite Foreman, Sample 120-748B-19H-4, 45-47 cm. 11. Clathrocyclas universa Clark and Campbell, Sample 120-748B-19H-4, $45-47 \mathrm{~cm}$. 12. Dictyoprora mongolfieri (Ehrenberg), Sample 120-748B-19H-7, 45-47 cm. 13. Lychnocanoma babylonis (Clark and Campbell), Sample 120-748B-19H-7, 45-47 cm. 14, 15. Sethocyrtis sp., Sample 120-748B-19H-4, 45-47 cm. Magnification of all figures is $175 \times$. 